Policy Research Working Paper 2014

Land Institutions and Land Markets

Klaus Deininger

Gershon Feder
Secure property rights to land and well-functioning land rental and sales markets are essential for creating investment incentives, improving the allocation of land, and developing financial markets. Yet regulatory restrictions on land rental and sales and regulatory frameworks providing inadequate tenure security are common. This paper looks at the impact of imperfections in other factor markets and the costs and benefits of government intervention to improve the security of property rights and the functioning of land markets and draws conclusions about land policy issues.

The World Bank

Development Research Group

Rural Development

November 1998

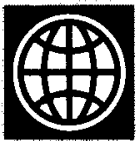


Policy Research Working Paper 2014

\section{Summary findings}

In agrarian societies land serves as the main means not only for generating a livelihood but often also for accumulating wealth and transferring it between generations. How land rights are assigned therefore determines households' ability to generate subsistence and income, their social and economic status (and in many cases their collective identity), their incentive to exert nonobservable effort and make investments, and often their ability to access financial markets or to make arrangements for smoothing consumption and income. With imperfections in other markets, the institutions governing the allocation of land rights and the functioning of land markets will have implications for overall efficiency as well as equity.

Deininger and Feder examine how property rights in land evolve from a situation of land abundance. They discuss factors affecting the costs and benefits of individual land rights and highlight the implications of tenure security for investment incentives. They also review factors affecting participation in land sales and rental markets, particularly the characteristics of the agricultural production process, labor supervision cost, credit access, the risk characteristics of an individual's asset portfolio, and the transaction costs associated with market participation. These factors will affect land sales and rental markets differently. Removing obstacles to the smooth functioning of land rental markets and taking measures to enhance potential tenants' endowments and bargaining power can significantly increase both the welfare of the poor and the overall efficiency of resource allocation.

Drawing on their conceptual discussion, the authors draw policy conclusions about the transition from communal to individual and more formal land rights, steps that might be taken to improve the functioning of land sales and rental markets, and the scope for redistributive land reform.

This paper - a product of Rural Development, Development Research Group - was prepared as background for the forthcoming Handbook on Agricultural Economics. Copies of this paper are available free from the World Bank, $1818 \mathrm{H}$ Street NW, Washington, DC 20433. Please contact Maria C. Fernandez, room MC3-542, telephone 202-473-3766, fax 202-522-1151, Internet address mfernandez2@worldbank.org. The authors may be contacted at kdeininger@worldbank.org or gfeder@worldbank.org. November 1998. (44 pages)

The Policy Research Working Paper Series disseminates the findings of work in progress to encourage the exchange of ideas about development issues. An objective of the series is to get the findings out quickly, even if the presentations are less than fully polished. The papers carry the names of the authors and should be cited accordingly. The findings, interpretations, and conclusions expressed in this paper are entively those of the authors. They do not necessarily represent the view of the World Bank, its Executive Directors, or the countries they represent. 


\section{Land Institutions and Land Markets}

Klaus Deininger

and

Gershon Feder 


\title{
Land Institutions and Land Markets
}

\author{
Klaus Deininger and Gershon Feder
}

\section{INTRODUCTION}

In agrarian societies land is not only the main means for generating a livelihood but often also to accumulate wealth and transfer it between generations. The way in which land rights are assigned therefore determines households' ability to produce their subsistence and generate marketable surplus, their social and economic status (and in many cases their collective identity), their incentive to exert nonobservable effort and make investments, and often also their ability to access financial markets or to arrange for smoothing of consumption and income.

Given this context, markets in which to exchange rights to land can provide a low-cost means to effect transactions that would bring this factor of production to its most productive use. The institutions governing the functioning of land markets will affect the transaction cost associated with such exchanges, the magnitude and distribution of the benefits generated by them, and the incentives for rational economic agents to undertake efficiency-enhancing transfers and land-improving investments. Furthermore, since land is one of the best collateral assets available, clearer property rights and greater ease of their exchange are likely to affect the emergence and efficiency of financial markets. This implies that land markets have an essential role in the broader process of economic development.

In this paper we first examine the way in which property rights in land evolve in an ideal and undistorted environment. We view the emergence of land rights as an endogenous response to increased scarcity of land and the associated incentives for land-related investment and then discuss other factors such as further increases in population density, better access to markets, or the introduction of improved technology to exploit the land, that would lead to increased productivity of agricultural cultivation, as well as endogenous technical change. We note that, historically, there have been few cases where such an uninterrupted evolution has been followed and briefly sketch the conditions required as well as the deviations from this ideal path. With this in mind, we discuss factors affecting the costs and benefits from individualized land rights and examine empirical evidence for their magnitude. In particular, the implications of tenure security for investment incentives are highlighted.

Having clarified the concept of property rights in land, we turn to land sales and rental markets. To do so, we consider the main factors affecting participation in those markets, in particular characteristics of the 
agricultural production process, labor supervision cost, credit access, the risk characteristics of an individuals' asset portfolio, and the transaction costs associated with market participation. These factors will affect land sales and rental markets differently; in particular, even if owner-operated farms are more productive than wage-labor operated ones, the sales market will not necessarily shift land to them. This implies that, in environments where financial markets are imperfect, land market operation needs to be considered within a broader perspective focusing on access to other markets and the availability of alternative assets. We note that, in general, land rental markets would be less affected by these problems because renting out does not preclude the landlord from utilizing land as a collateral to access credit which could then be passed on to the tenant in an interlinked contract. Removing obstacles -often government regulations or imperfections in other markets- that prevent smooth functioning of land rental markets and taking measures that enhance potential tenants' endowments and bargaining power, can considerably increase both the welfare of the poor and overall efficiency of resource allocation. There are also many instances where sales markets are regulated in a manner which hampers incentives for socially optimal behavior. In addition to reducing tenure insecurity, governments can in these situations improve the efficiency of resources use by avoiding interventions limiting rental and sales market.

Finally, in a number of countries, a highly unequal land ownership distribution implies inefficient and inequitable resource use which the land sales or rental markets are not able to smoothly transform into a more efficient and equitable allocation. Based on these issues we draw policy conclusions concerning the transition from communal to individualized land rights and the award of titles, steps that might be used to improve the functioning of land sales and rental markets, and the scope for redistributive land reform.

\section{PROPERTY RIGHT TO LAND}

\subsection{THE EMERGENCE OF LAND RIGHTS}

The process of gradual individualization of property rights in land can be conceived as an induced institutional response to higher shadow prices of land to encourage longer term investments in land, as in the pioneering analysis by Boserup. ${ }^{1}$ At the earliest stages of development, even before the establishment of sedentary agriculture, tribes of hunters and gatherers assert control over certain locations where they collect food and engage in hunting. As population density increases, forest fallow systems, and then communal property right systems emerge. Under these arrangements, the general right to cultivation of a

\footnotetext{
'It is well understood that this idealized process has rarely been followed in actual history (Boserup herseif devotes more than one chapter to the issue of coercion and the description of feudal systems). It is, nonetheless, useful to illustrate the main underlying factors.
} 
piece of land is an inseparable and in principle inalienable element of tribal membership. Gultivation rights are assigned to individuals on a temporary basis, normally as long as the cleared plot is cultivated. Once cultivation has ended (due to exhaustion of soil fertility), the plot falls back to the community and the family either selects a new plot (if land is abundant) or has a plot allocated by the chief of the tribe. The fact that land is held by the community rather than the individual facilitates periodic redistribution of at least part of the land among community members based on population growth, serving as a social safety net and preventing the emergence of a class of permanently landless individuals. Tenure security in a general sense is very high, i.e. individual members enjoy secure and inheritable general rights to cultivable land which can be reactivated even after a period of absence.

As the relative scarcity of land increases, the pledging or intra-community rental of land emerges. This practice, whereby land that is not used can temporarily be pledged to another family, with the stipulation that it has to be returned upon request, facilitates the productive use of land in case the original owner is unable to undertake cultivation. It is distinctly different from permanent land transactions and is generally not allowed to involve people from outside the community? It also does not uniformly apply to all land unimproved land lying fallow at any given time continues to be at the free disposal of the community for example for grazing by domestic animals owned by any family with cultivation rights. Variations of such communal tenure systems where parcels are re-allocated from time to time in order to accommodate population growth and grazing land is left for communal use are common in many parts of the developing world such as China, large parts of Africa, and Mexico.

What are the factors driving this process of successively increasing precision in the definition of property rights to land? The most frequent explanation is that a virtuous cycle of technical change and investment is set in motion by a combination of increasing population density, technical progress, commercial integration, and reduction of risk. Boserup was the first to point out the fact that, historically, higher population density was the driving force behind an endogenous process of better definition and enforcement of property rights, changing arrangements for the organization of production, and higher levels of investment.

The Boserupian framework of changes in the relative scarcity and of land use of labor-saving technology can, for example, explain systematic changes in the strength of womens' land rights (Platteau 1998b). Under land abundance and predominance of shifting cultivation, agriculture tends to be female-

\footnotetext{
${ }^{2}$ Indeed, the distinguishing characteristic of communal tenure systems is not a lack of general tenure security but the fact that property rights are not permanently linked to a specific plot, implying the existence of restrictions on the transferability of land rights (especially to individuals who are not members of the community).
} 
dominated, polygyny is widespread, and women enjoy high status as workers as well as childbearers. Marriage is accompanied by the transfer of bridewealth to the bride's family and, in case of the husband's death, women retain land rights either in their native or in their new village. With greater increased land scarcity and adoption of the plough the importance of women in agricultural production tends to decline and bridewealth, as well as customary safeguards to protect widowed and isolated women disappear. Instead, upon marriage the women receives a pre-mortem inheritance in the form of dowry which -as it remains the property of the wife- establishes a threat point in intra-household bargaining and provides economic security in the case of divorce or death of their husband.

The diffusion of exogenous technical change and/or expansion of trade generally have an investmentincreasing effect similar to the one caused by increased population density. By increasing the stream of incomes that can be derived from a unit of land, they augment incentives for better definition of property rights in land. Indeed, establishment of tree crops, and the associated heavy investment in clearing and leveling of land, was generally only undertaken where institutional innovations had enhanced tenure security adequately so that individuals could be sure to reap the benefits from such investments. Similarly, the transport revolution caused by the steamship in the late 19th century led not only to the incorporation of hitherto unexplored countries and states into global trade but also increased the demand for individualized ownership of land. For example the opening of Thailand to international rice trade through the Bowering treaty of 1826 induced a quantum increase in the demand for rice land in the Thailand plains, and brought about the introduction of a formal land registration system (Feeny, 1982), induced a quantum increase in the demand for rice land in the Thailand plains, and brought about the introduction of a formal land registration system.

Another important factor furthering the evolution of individual property rights to land is the reduction of risk to income and consumption. The three major avenues for this to come about are (i) the development of markets for output, capital, and insurance; (ii) technical progress that allows diversification, reduction of the covariance of yields, and the probability of crop failure, and (iii) the emergence of access to noncovariate streams of off-farm income. It has long been noted that group ownership of land (or joint communal production) can be viewed as an "insurance policy" to eliminate the threat of permanent assets loss or to reduce vulnerability to idiosyncratic consumption shocks. However, the scope for using communal land ownership to insure against non-idiosyncratic shocks is limited by the weather-induced covariance of agricultural production. Especially when it entails collective production, ${ }^{3}$ the costs of

\footnotetext{
${ }^{3}$ Group ownership has often been prevalent where risk is high and where factors such as remoteness, environmental hazard, or presence of external enemies, imply that superior insurance mechanism are not available (Ellickson 1993).
} 
collective production are high and individuals to prefer individual ownership once alternative and less costly mechanisms to insure against covariate risks become available (see Key et al. 1998 for the case of Mexican ejidos) 4

It is well known that, because monitoring of effort in agricultural production is very difficult and costly, collectives where individuals are not residual claimants to profits are highly inefficient forms of agricultural production (Deininger, 1993). However, contrary to widespread misconceptions, communal tenure systems are generally not based on collective production. Instead production on arable plots is normally undertaken by individuals who are residual claimants to output implying that, on arable plots, incentives for effort supply by individual cultivators are likely to be appropriate. Inefficiencies may persist with regard to either the longer-term sustainability of decisions concerning the use of communal areas such as forests and pasture or the disincentive to invest deriving from the inability to claim ownership rights to specific plots. In an analysis of Mexican farming communities (ejidos), McCarthy et al. (1997) provide empirical evidence for the existence of collective action problems regarding the use of pasture and forest, but not of individually managed plots.

Communal resource ownership is often motivated by the ability to provide benefits in the form of easier provision of public goods, arrangements to enhance equity, or the ability to take advantage of synergies that would be difficult to realize under fully individualized ownership. Examples include risk-reduction through diversification advantages in highly variable environments (Nugent and Sanchez 1994), the utilization of economies of scale to break seasonal labor bottlenecks (Beard 1996; Mearns 1996), or investment in community-level infrastructure (Boserup 1965; Dong 1996)..$^{5}$ As long as effective means of governance and accountable institutions at the local level are available, these systems can -especially in situations when there is need for community-level investment- be very effective. For example, under the medieval open field system, cultivation decisions were made collectively but monitoring-sensitive tasks were carried out on an individual basis. This allowed utilizing economies of scale in fencing, harvesting, shepherding, and risk diversification through strip-cropping without compromising the advantages of individual effort supply (McCloskey 1975 and 1991; Townsend 1993; Blarel et al. 1992).

The usufructuary rights given under communal tenure systems do not impose large losses as long as population density is low and land is relatively abundant, pay off for making long-term investments is

\footnotetext{
4. The potential usefulness of communal land ownership as a device for consumption- smoothing is inversely related to the incidence of locally covariate climatic shocks. It is thus not surprising that, at comparable levels of population density, communal tenure systems have proven to be more durable in environments where such risks are lower.

${ }^{5}$ An interesting case to illustrate this is made by Ellickson (1993) who compares different settlements (Jamestown, Plymouth, Salt lake City, and the Bermudas) to suggest that, while many frontier settlements started out with group ownership and production to utilize economies of scale in
} 
low, and definition of individual property rights in land is costly. However, even though individuals have the right to cultivate specific plots (a measure that avoids the efficiency losses due to collective production), the lack of permanent rights that is implied by the periodic re-distribution of plots may decrease incentives to make long term land-related investments under communal arrangements. A similar effect comes thorough the limitation of land transfers to members of the community and the inability to utilize land as a collateral for credit.

Improved access to markets, infrastructure, and financial intermediation, are alternative ways to provide the benefits -in terms of insurance, diversification, and access to funds for investment- associated with communal forms of land ownership. At the same time these exogenous factors increase the costs -in terms of investment disincentives and foregone land transactions with outsiders- associated with traditional land ownership systems. This implies that, with economic development, the relative attractiveness of communal systems will decrease and, at some point, it would be economically rational for a community to allocate permanent and fully tradable ownership rights to individuals (see Thompson and Wilson 1993 for Mexico), completing the transition from a communal to an individualized tenure system.

However, instead of following an smooth endogenous evolution along the lines outlined above, the transition to individual property rights has in the large majority of historical cases been affected by exogenous interventions. As population growth increases the relative scarcity of land, one observes a general increase in boundary conflicts and social tension. 6 In the absence of strong and representative community-level institutions, this often leads to appropriation of property rights to the communal resources by powerful individuals, by and abuses of power and land grabbing through local chiefs and headmen. ${ }^{7}$ These phenomena are often seen as a major course of environmental degradation and increased social tension and inequality that leaves out the poor and vulnerable.

History demonstrates that regions with potential for agricultural or non-agricultural exports were generally characterized by the appropriation of large tracts of lands through imperialist, colonial, or other overiords who either replaced local chiefs and elders, or tried to co-opt them to enforce their rule. These changes undermined traditional tenure systems, the associated structures of accountability, and thus the institutional underpinning of the organic evolution of such systems (Downs and Reyna, 1993; Feder and

defense and other activities, the length of maintaining group ownership can be related to the riskiness of the environment, the frequency of social interaction and the hierarchy structure of decision-making.

"Zimmerman and Carter (1996) show that incorporating agent heterogeneity, risk, and subsistence constraints can facilitate a more differentiated assessment of the welfare- and productivity-impact of a given institutional innovation (e.g. the adoption of marketable land rights) on different groups of producers.

${ }_{7}^{7}$ For example, despite extremely low levels of population density in Zambia, almost $50 \%$ of small producers feel that their security of tenure is insufficient and are willing to pay (a mean amount of US \$40) for getting secure ownership rights (Deininger et al. 1998). Low-cost means of 
Noronha 1987). ${ }^{8}$ Furthermore, once they discovered that access to labor rather than land was the most limiting factor, overloads generally introduced distortions in other markets to reduce the reservation utility of independent farmers and to assure a supply of labor for export production in mines or for the newly established estates. In addition to reducing the reservation utility that cultivators could obtain from independent cultivation, such restrictions have contributed to widespread rural poverty and retarded development of competitive markets in rural areas, often laying the basis for continued rural-urban dualism.

In more recent times, Governments have, through implicit and explicit taxation, drained the rural sector of resources that could have fueled a process of increased markets integration and technology development while at the same time higher rates of population growth vastly increased the need for new technology and better infrastructure (Schiff and Valdes 1995). The associated lack of markets and technological opportunities has, in a number of cases, contributed to a situation akin to the "involution" that had earlier been diagnosed for Asian systems (Geertz 1960), with far-reaching implications for the structure of resource ownership rights. For example in Rwanda, with very high population density (787 persons per $\mathrm{km}^{2}$ ), traditional systems of land allocation have become defunct and fail to provide even the most basic services they were designed for (Andre and Platteau 1996). As traditional limitations on land sales have been discarded, speculative land purchases by individuals with access to non-covariate offfarm income lead to a rapid dis-equalization of landholdings. 9 While costly land disputes consume productive energy, environmental degradation continues unabated and the return to an idealized notion of "communal property rights" is unlikely to be a feasible option. To judge, however, what alternative arrangements would be feasible, it is necessary to consider in more detail the costs and benefits associated with different tenurial arrangements.

Drawing together the evidence on costs and benefits associated with more secure and fuller property rights arrangements, three conclusions emerge. First, where population density is sufficiently high, increased tenure security -not necessarily equivalent to formal title- has an important impact on increased investment. Second, there is some evidence that a higher degree of transfer rights provides additional incentives for investments and for more efficient use of family labor. Finally, the ability to use land as collateral to increase access to medium and long term formal credit markets is of importance if

increasing tenure security and reducing encroachment from outside through better accountability and issuance of community-titles could possibly increase welfare and tenure security.

${ }^{8}$ This was independent of whether the intervention was associated with the elimination of traditional tenure systems in favor of individualized rights to the selected group, as in many parts of Central and Latin America, or the use of local chiefs and dignitaries as intermediaries for the central power as in African countries.

"It is of interest to note that about $65 \%$ of sales are classified as distress sales -the incidence of which is not restricted to the lowest landholding group- and an additional $17 \%$ of lands are sold to cover litigation expenses, often arising from land disputes. 
foreclosure is feasible. Studies that compared the financial costs and economic benefits of titling program suggest that high rate of return are possible but that, unless measures to reduce the transaction costs associated with administering credit to smallholders are undertaken, the benefits associated with titles may not accrue equally to all types of farmers.

\subsection{BENEFITS AND COSTS OF INDIVIDUALIZED PROPERTY RIGHTS}

The main benefits from well-defined and secure individual property rights relate to (i) greater incentives for (and lower costs of) long-term resource conservation and the associated increased demand for investment; (ii) improved transferability (temporary or permanent) of land to cultivators who have the resources to make better use of it and (iii) the ability to use land as collateral in formal credit markets, a benefit that is more significant where formal title exists and land transactions are actually feasible. These benefits need to be weighed against two main types of costs: the administrative and logistical expense associated with definition of boundaries, enforcement of rights, and resolution of disputes among claimants, and the increased risk of losing a safety net provided by communal control of land.

\subsubsection{Benefits from individual land rights}

Improved tenure security brought about by individualized land rights will be associated with static and dynamic benefits. Even without having full long-term security of tenure, individual cultivation rights that entitle an individual to residual claimancy of profits generated on a plot mark the difference between collective and private forms of cultivation. The transition from collective to private cultivation has historically been associated with large increases in productivity, as for example in the case of China (McMillan et al. 1989, Lin 1992, Lin et al. 1994) However, equally important benefits from better defined long-term property rights would come about in an inter-temporal setting where higher security of tenure would increase the incentives for long-term investments, the incidence of productivity-enhancing transfers, and the supply of credit to make such investments. These aspects are elaborated upon below.

\section{Tenure security}

Conceptually, insecurity associated with the lack of well-defined property rights can be understood as a random probability of loss of future income due to conflicting challenges. Eliminating such a threat through informal institutions (customary tenure) or formal institutions (land titles) will clearly increase the subjective payoff from productivity-enhancing long-term investments and thus the owner's 
willingness to undertake them. While the theoretical expectation is straightforward and easily formalized (see for example Feder et al. 1988; Besley 1995), the critical question, and much empirical debate, has focused on the magnitudes of such effects in a different settings.

The analysis of different types of land rights in Africa is complicated by the need to take in account for the potential endogeneity of investment (Besley, 1995). The reason is that there may be certain types of investments -from marking of boundaries to planting of trees and hedges, and building of houses or sheds- that may be undertaken with the primary purpose of establishing implicit property rights to land rather than to increase productivity (Brasselle et al. 1997). Depending on how such actions affect the probability of land loss and whether or not there are community rules to provide (partial) compensation for such investments when a plot reverts to the community, it is easy to construct scenarios where communal tenure systems may increase rather than decrease the amount of land-related investment undertaken (Sjaastad and Bromley 1997), 10

The key result from a number of studies that have investigated the investment-enhancing effect of tenure security is that, under formal as well as informal regimes, tenure security -as measured by the extent of rights possessed by the owner- significantly affects farmers' investment decisions. Especially where investments are labor-intensive but involve few cash outlays, the unambiguous conclusion is that higher levels of tenure security -even if they are not associated with high levels of transferability and defined only at an informal level- do indeed provide an important incentive for increased investment. 11

Evidence from one of three study areas in Ghana indicates that greater tenure security at the plot level significantly increases the probability that individuals will plant trees, and undertake a wide range of other investments such as draining, irrigating, mulching, etc. (Besley 1995). The fact that field-specific rights but not mean household rights can be shown to be significant, suggests that plot-level tenure security, rather than credit supply effects accruing to the household as a whole, are likely to be at the root of this relationship between tenure security and investment.

Results from China confirm the importance of tenure security for investment. Comparing plots planted to the same crop within the same household but under different tenure regimes, it is found that farmers tend to apply more manure and labor, and obtain significantly higher yields, on plots that are privately owned and therefore more secure (Rozelle et al. 1996). This is the case even though the possible impact of

\footnotetext{
"11) Using comparative statics from a simple model it can be shown that communal as compared to individual tenure is more desirable from the individual's point of view as the discount rate increases; the productivity increase generated by investment is smaller compared to rent; the initial probability of eviction is low; and the probability of recovering investment even after eviction is high. A combination of these factors may cause individuals under indigenous tenure to commit resources to land improvement beyond what would be the case under individual resource ownership.
} 
greater tenure security on crop choice (shifting to orchards instead of growing maize) is not accounted for. Similarly, Yao (1996) finds that higher levels of tenure security in Chinese villages have a strong and very significant investment-enhancing impact (application of green manure). ${ }^{12}$ Analysis of the impact of higher tenure security through land titling in the Brazilian Amazon yields similar results (Alston et al. 1995 and 1996) and there is considerable amount of more anecdotal evidence on a positive association between availability of title and farm output or investment (see Binswanger et al. 1995 for references).

On the other hand in Niger, a more land-abundant setting, different degrees of tenure security between plots with full private ownership and plots held under usufruct, do not give rise to large statistically significant differences in application of manure, a medium term yield improving investment (Gavian and Fafchamps 1996). In this context, farmers apply significantly lower amounts of manure on rented as compared to owned plots, but there is no significant difference between parcels held under full private ownership and those held under "traditional" usufruct. The conclusion is that apparently tenure security on the latter is high enough for farmers to expect to be able to reap the benefits from their (medium term) investment. At a more general level, it indicates that, in order to determine whether specific property right arrangements are conducive to higher levels of investment, more detailed study is necessary and generalizations are unlikely to be helpful. What is instead required is a more differentiated judgment that takes account of the time horizon of the investment, the opportunity cost of the resources used, and the size and distribution over time of the expected payoff associated with the investment.

\section{Transferability}

Land markets tend to be highly localized. As a consequence, the ability to transfer land between users may be of limited importance in early stages of development when there is little heterogeneity of skills across the population and non-agricultural opportunities are limited. However, the importance and value of being able to transfer use or ownership rights to land increase with economic development, specialization, and better development of other markets. In this case, the transfer of land from those who have lower productivity to those who are able to make more productive use of the land improves the overall resource allocation. The demand for such exchanges increases further as the rural economy becomes more integrated geographically, facilitating transactions between individuals who are not members of the same community. Such situations generally involve larger problems of asymmetric

\footnotetext{
It This does not necessarily imply that actions to increase tenure security are warranted or even needed (Platteau, 1998).

12 At first glance this would seem to be at variance with the finding by Feder et al. (1992) who find that, for a similar sample from four Chinese provinces, neither short-term nor long-term tenure security -captured by farmers' perception about the possibility that their land may be reallocated before the expiration of the current 15 -year contract. One can reconcile the two findings by noting thatFeder et al.'s study considers non-attached investment (machinery, livestock, and construction) which should not be affected by individual plots' tenure security, that access to
} 
information and greater benefits from more formal systems of land ownership recording. If the ability to liquidate investments (through land transfers) increases the incentive to undertake such investments, higher levels of transfer rights, and the greater ability to affect transfers which is entailed in formal land rights systems, will not only improve resource allocation but will also be associated with higher levels of investment and labor use by individual cultivators.

The only data that allow testing of this hypothesis come from China where one observes variability in systems of transfer rights in different communities (Carter and Yao, 1998). Results suggest that higher levels of transfer rights increase investment (application of green manure). In addition, evidence from China indicates that higher levels of transfer rights also induce a better allocation of the households labor endowments in response, for example, to outside employment opportunities. Households with higher levels of transfer rights apply less labor on their farm and devote more time to more remunerative offfarm activities (Yao 1998), thereby contributing to equalization of factor ratios within a village and increasing overall efficiency. More indirect support for an important efficiency-increasing (but not investment enhancing) impact of higher transfer rights is provided by Rozelle et al. (1997) who find that an increase in off-farm opportunities narrowed the difference between labor spent on (transferable) private and (non-transferable) communal plots. 13

\section{Credit access}

In addition to inducing investment, secure land ownership is likely to increase the supply of credit from the formal credit system to undertake such investment. The reason is that, because of its immobility and virtual indestructibility, land with secure, clearly defined, and easily transferable ownership rights is an ideal collateral. The provision of a collateral -facilitated by possession of formal land title- is generally a necessary condition for participation in formal credit markets for medium and long-term credit. In fact, there is evidence of titles facilitating access to informal (but impersonal) credit markets as well (Siamwalla et al., 1993). Existence of well documented and transferable property rights and of institutional arrangements to facilitate the low-cost transfer of land are likely to make an important contribution to the development of financial markets.

However, while use of titled land as collateral can, under the condition that foreclosure is socially feasible, reduce a bank's default risk and thereby enhance credit supply, it will have little impact on the

working capital emerged as being an important determinant, and that the subjective measure of tenure security used by them is more noisy than the index of land tenure security used by Yao.

${ }^{13}$ Evidence is not uniform: for Ghana, the hypothesis that sales and rental rights do not have a significant impact on investment decisions can not be rejected (Besley 1995). This suggests that the prospect of being able to transfer land more easily through sales and rental markets in the future is, in this environment, not an important consideration in individuals' decision to effect land-related investment. 
transaction costs associated with administering credit to small producers in rural areas. In environments where these costs are high, the improved credit-worthiness brought about by possession of land title may therefore not be enough to facilitate access to formal credit by small farmers. Unless complementary measures to reduce transaction costs and ensure access to credit by this group are undertaken alongside with individualized property rights through titling, the benefits from titling programs may accrue only to medium and large landowners.

The importance of the credit supply effect associated with provision of land title is supported by evidence from Feder et al.'s (1988) study in Thailand, where farmers' opinions and econometric evidence point towards improved credit supply as the main benefit from titling. Land ownership titles induced higher investment in farming capital (attached investments and other capital), 14 titled land had significantly higher market values and higher productivity per unit. In three of the four provinces covered, households' credit supply had been significantly enhanced by the availability of title. By contrast, and in line with the above, title was found to have little impact on either investment or farm income where formal credit markets were not available (Atwood 1990, Carter and Wiebe, 1994; Migot Adholla et al. 1994). ${ }^{15}$

Additional evidence from a study based on panel date from Paraguay indicate that titling had a positive income or productivity enhancing effect through credit market benefits for at least some groups of farmers. Due to a strong impact of formal title on both credit supply and investment demand, the benefits from title are relatively large (about $10 \%$ of farm income), and significantly higher than the cost of titling. However, the impact of awarding titles was strongly size-differentiated. Estimates indicate that producers below 20 hectares remained rationed out of the credit market and therefore did not benefit at all from the credit-supply effect of title (Carter and Olinto, 1996).

This differential impact suggests that, in environments where other markets (such as credit markets) entail distortions which put smaller and poorer farmers at a disadvantage, individual property rights on equity, and -in the medium to longer term- on the direction and nature of land transfers between different size classes of producers, could imply greater inequity. Whether, in the presence of heterogeneity in endowments, small producers will benefit from such policies depends critically on the ability to reduce, together with titling, transaction costs and policy induced distortions that limit access to credit markets.

\footnotetext{
${ }^{14}$ Problems of endogeneity and self-selection are circumvented by drawing samples from squatter villages in areas nominally under public ownership (where titles could not be awarded) and private areas where all residents already had obtained titles.

${ }^{15}$ Pender and Kerr (1996) show that for India land ownership has little impact on credit supply, a fact that is attributed to severe non-price rationing. Nonetheless, land values for titled land are on average about $15 \%$ higher than for untitled land, suggesting that possession of formal title reduces the probability of land loss for potential buyers.
} 


\subsubsection{Costs}

The most obvious cost associated with formal definition of property rights in land is the expenditure needed to physically demarcate and delineate plots, to establish and maintain accurate records of land ownership, and to enforce these rights and resolve whatever disputes might arise. ${ }^{16}$ These costs are borne by individual land owners in situations, for example frontier settlement, where public enforcement of property rights is absent and individuals make defensive investments such as guards, fences, and other demarcation devices to demonstrate the legitimacy of their claims to property and to defend such rights against possible intruders (Muller, 1997). It has been shown that the privately "optimal" amount of spending by individuals on means of protection will be inefficient from a social point of view (Feder and Feeny; de Meza and Gould 1992). Furthermore, the defensive activities undertaken often have little social value and may generate negative externalities, an issue that has been emphasized with respect to the Brazilian Amazon where the need to demonstrate "productive" land use to establish ownership claims has been linked to increased deforestation (Binswanger 1988, Southgate et al. 1991). Even where they are not associated with externalities, defensive activities that are often undertaken in speculative attempts to secure "ownership" of large tracts of land, can lead to complete dissipation of the rents to be had (Allen 1991). 17

Given the undesirable impacts of private rights enforcement, public provision -in the form of land records, police, and a judiciary- would therefore be preferable in all situations except ones characterized by very low levels of population density (Malik and Schwab, 1992). This is indeed observed throughout human history. The specific form in which land records are established will still depend on the relative costs and benefits from such an activity - something that depends partially on the technology and infrastructure available for record keeping. 18 At initial stages of human development assignments of property rights appear to have been handled orally by the community (with community functionaries holding public sessions at the gate, for example). However, the benefits from keeping written records seem to have been so great that across a large number of cultures, officially validated land records are among the first documents to appear once a written language had been developed (Ellickson 1993). 19 In addition to establishing unambiguous ownership rights, written records do allow to verify the ownership status of land at low cost, thus reducing the scope for asymmetric information about ownership and quality of land and making land sales and

\footnotetext{
${ }^{16}$ Note that the number of disputes is itself endogenous, depending on the type of property rights system chosen.

${ }^{17}$ Spontaneous collective action to limit the dissipation of resource rents associated with individualized defense of property rights has been observed in a number of cases where group sizes were small (Umbeck, 1977).

${ }^{18}$ Ellickson (1993) notes that historically the establishment of formal land rights is closely related to the emergence and widespread use of written language; in many cultures records of land transactions were among the first texts that have been officially recorded.

"See, for example the Indian Arthsastra from the 4th Century BC as well as references in the Bible relating to the period $600 \mathrm{BC}$.
} 
rentals cheaper to implement. This reduction of transaction costs would increase the liquidity of the land market and could bring the number of efficiency-enhancing transactions closer to the optimum, i.e. helping to transfer more land from less productive to more productive individuals.

A second type of social cost associated with fully individualized property rights relates to the fact that, at low levels of development, communal land ownership may perform an important insurance function that would be eliminated by establishing fully individualized property rights in land. 20 Furthermore, it has long been known that in cases where other markets are highly incomplete, land sales markets may not automatically transfer land to more productive users. In such situations, individualization of land rights could be doubly disadvantageous (see Platteau, 1998 for references). On the one hand it could pave the way for the emergence of sales markets that deprive traditional communities of their source of livelihood (often without adequate compensation), thus generating social unrest and violence and eliminating an important form of insurance. On the other hand, where land rights are introduced in such an environment, productivity will not necessarily increase as availability of land rights could induce concentration of landholdings by a privileged minority of wealthy individuals who -for example by having access to noncovariate sources of income- are in a position to accumulate land for speculative purposes without making productive use of this asset. 21

Historical evidence does indeed suggest that, in situations where other markets are not well developed or where policy-induced distortions affect the functioning of land markets, increased transferability of land may deprive the poor of an important social safety net. The importance of the insurance aspect is confirmed by the fact that, even where societies have made the transition to individualized land rights, they have often maintained land-related social safety nets to provide insurance for the poor. One example for a mechanism to do so is to allow continuing uses of communal pastures and forest areas of low productive value as well as an universal right to collect leftovers after the harvest or graze animals on harvested fields. Another one is the provision for periodic redistribution of at least part of the land available to the community - for example the Bible mandates land redistribution every 50 years. ${ }^{22}$ Such redistribution of cultivation rights is likely to decrease productive efficiency by attenuating individuals'

\footnotetext{
201 Jodha (1990) provides evidence on the importance of access to the commons as a safety net for the poor. Based on panel data from China, Burgess (1997) finds that the equitable allocation of land use rights under communal tenure has an effect similar to a lump sum transfer that provide insurance against low nutritional outcomes in a way that is more incentive-compatible than anex post redistribution. The fact that land ownership has a more significant impact on improving nutrition than on income can be explained by the fact that, with imperfect rural grain markets, considerable cash outlays would be required to achieve a similar effect through market purchases of grain. The presence of equity benefits from periodic redistribution of land rights in China would be consistent with peasants' strong support for the system of periodic redistribution (Kung, 1995).

${ }^{21}$ Note that this is historically well-founded, as the many examples in Binswanger et al. (1995) demonstrate.

22 If incentive structures and enforcement mechanisms to ensure that such provisions are actually implemented at the local level are non-existent, the provision for regular redistribution can actually give way to arbitrary behavior and rent extraction by local leaders. For a theoretical and empirical discussion of these issues see Turner et al. (1998).
} 
incentive to make plot-specific investments. The fact that societies have been willing to incur these efficiency losses suggests that the subjective valuation of the benefits in terms of avoiding widespread landlessness, social destitution, and discontent, has been high. This implies that where land is an important asset for poor and marginal groups, both social and efficiency aspects associated with land rights need to be accounted for in assessing the potential benefits from individualizing land tenure arrangements.

\section{LAND MARKETS: FUNCTIONING AND EFFICIENCY IMPLICATIONS}

If there are differences in individuals' skills and endowments of different factors of production, markets should help in optimizing factor proportions employed and thus increase overall efficiency of resource allocation. This section aims to outline the main determinants that would affect participation in the land sales or the land rental market, and based on this to elaborate on links and differences between these two markets, in terms of their impact on equity and efficiency of resource allocation.

The productivity advantage of small farmers who rely predominantly on family labor rather than on less motivated hired workers who have to be supervised would imply that, in the absence of imperfections in other markets, a functioning land market should facilitate efficiency- and equity-enhancing transfers from large to small producers - or from ones with lower management skills to better operators. However, land sales transactions could be efficiency decreasing if, due to policy induced credit market distortions, large owners' advantage in accessing credit would offset the productivity advantage of owner operators or if, due to the inability to insure, significant land holdings are not part of poor people's optimal asset portfolio 23 Thus, before actions to activate the land market are undertaken, careful empirical investigation of the functioning of financial markets and insurance mechanism, and possibly steps to improve their functioning, might be in order.

Even if imperfections in markets for credit and insurance reduce the scope for the land sales market to bring about improved land allocation through land transfers from large to small producers, such allocation shouldin a frictionless world- be facilitated through the land rental market. One possibility would be an interlinked contract whereby the landlord uses the credit access provided by land ownership to provide the tenant with working capital as part of the rental contract. High transaction costs - part of them related to government regulation- reduce the extent of land rental transactions in a number of countries. Examining the

\footnotetext{
${ }^{23}$ Indeed, there is descriptive evidence indicating that in environments with imperfect credit market access, e.g. in Africa, land sales markets result in an efficiency-reducing transfer of land from small to large producers (Collier 1989).
} 
implication of regulations in more detail would be of importance as removing unjustified interventions is likely to go a long way towards improving resource allocation in agricultural systems characterized by very unequal land distribution. Most rental markets in developing countries involve some form of share tenancy. While this arrangement does not lead to full efficiency, it is a second best solution given risk and imperfect capital markets. The sections below elaborate these points and review relevant evidence.

\subsection{KEY DETERMINANTS OF LAND MARKET PARTICIPATION}

The shadow price of land for different types of heterogeneous agents is determined by the agricultural production function, the households' inherent managerial ability, and by a number of imperfections in labor, credit, and land markets that are common in rural areas. If credit and land rental markets were perfect, the supervision costs associated with the use of hired labor would make smaller farms more productive, and would lead households to lease in or lease out the amount of land required to maintain a uniform ratio of family labor endowment to operated area, irrespectively of the land ownership distribution (Feder 1985). However, imperfections in other markets may change this, with implications for the functioning of land rental and sales markets. If, in the presence of credit market imperfections, supply of working capital depends on the amount of land owned, the optimal size of the operational holding would vary systematically with size of the owned holding even if land rental markets were perfect. While the magnitude (and direction) of this effect would depend on the elasticity of output with respect to effective labor and of labor effort with respect to supervision, it can overwhelm the productivity advantage of family farmers and give rise to a positive relationship between owned farm size and productivity. In addition to this, capital and insurance market imperfections may also affect the production activities of poor producers - possibly leading them to pursue less risky but also less productive activities. Below we review the factors which affect the productivity of farmers, and thus determine their demand for land.

Economies of scale: The presence or absence of economies of scale would systematically affect the shadow price of land for different farm-size classes. Possible economies of scale could arise from the presence of indivisible factors of production or cost elements leading to an initial range of farm size where the average cost of production declines with farm size. In cases where other markets function reasonably well, optimal farm sizes tend not to exceed the scale at which family labor is fully occupied (utilizing seasonal hired labor for specific tasks). ${ }^{24}$ Agricultural activities where significant economies of scale in the production process

\footnotetext{
${ }^{24}$ A large number of empirical studies (e.g. Olson-Lanjouw 1995 for India, Feder et al. 1992 and Burgess 1997 for China, Olinto 1995 for Paraguay) are indeed unable to reject the hypothesis of constant returns to scale in agricultural production.
} 
exist are few. 25 Some economies of scale are associated with the processing and marketing of many agricultural products, but this does not have important implications for the unit cost of farming operations as long as competitive markets for outputs and inputs exist. Alternatively, access to such markets is sometimes arranged through cooperatives. Only for a few "plantation crops" such as sugarcane, bananas, or tea could the need for immediate large-scale processing or marketing transmit economies of scale from the processing stage to production. To reap the economies of scale associated with the former, production of these crops is generally organized on a scale that corresponds to the optimum scale of the processing factory. 26

Labor supervision cost: Constant returns to scale would imply that the size of agricultural operations has little impact on productivity. However, the need to supervise hired labor would confer a productivity advantage on owner-operated farm units. The fundamental reason for this is the presence of agency costs (Jensen and Meckling, 1976), which result from the need to manage wage labor and enforce effort in largescale operations. The lack of incentives for wage workers to exert effort, and the consequent need to supervise labor or to offer incentive contracts, has received considerable attention in industrial organization literature (Jensen and Meckling 1976), and is recognized to have profound implications for the organization of production and for the optimal size of the firm (Calvo and Wellisz, 1978; Eswaran and Kotwal 1985a and $1985 \mathrm{~b}$ ). The cost of supervision is particularly large in agricultural production due to spatial dispersion of the production process and the need to constantly adjust to micro-variations of the natural environment. Family members are residual claimants to profits and thus have higher incentives to provide effort than hired labor. 27 They share in farm risk, and can be employed without incurring hiring or search costs. These attributes underlie the general superiority of family farming over large-scale wage operations, manifested empirically in an inverse relationship between farm size and productivity. A large number of studies based on aggregate, or cross-sectional, and panel data have confirmed the existence of the inverse farm-size productivity relationship for all but the smallest farm size classes (Berry and Cline 1973, Carter 1984, Benjamin 1995, Newell et al 1997, Kutcher and Scandizzo 1981, Olinto 1995, Burgess 1997, Udry 1997). 28 Thus, unless there are other countervailing forces, one would expect land markets to transfer land from large to small producers. We turn now to discuss these countervailing effects.

\footnotetext{
${ }^{25}$ Exceptions are limited to cases of highly specialized machinery, specialized livestock production, or plantation crops where economies of scale are transmitted from the marketing to the production stage.

${ }^{26}$ However, the supervision advantages of pwner-operators have in many cases motivated large processors to contract production out to smallholders under outgrower or contract farming schemes, often providing credit in kind as well as technical assistance (Glover 1990).

${ }^{27}$ Empirical evidence confirms that family labor is more productive than hired labor, and that the intensity of supervision by family members affects the performance of hired labor (Frisvold 1994)

${ }^{28}$ Bhalla and Roy (1989) and Benjamin (1992) have shown that from cross-section analyses (e.g. Berry and Cline 1973, Carter 1984, Newell et al 1997, Kutcher and Scandizzo 1979) tend to overestimate the productivity advantage of smaller farms if soil quality is not specifically accounted for.
} 
Credit market access: A key reason for land markets' transfer from large to small producers to be rarely observed is that it is very difficult for small farmers to access markets for credit and insurance. 29 This implies that, on the one hand, the value of accessing credit markets is capitalized in land prices, making it very difficult to acquire land in the sales market with the expectation of paying off the debt from agricultural profits alone without recourse to equity. On the other hand, credit market imperfections that increase the shadow price of credit for small producers would reduce small farmers' competitiveness in the land sales market and at the same time outweigh the supervision cost advantage they enjoy.

Asymmetric information and moral hazard lead generally to quantity rationing in credit markets (Stiglitz and Weiss, 1981). Formal credit markets can overcome the problem of asymmetric information by utilizing a collateral requirement. However, the costs of and political impediments to foreclosure on smallholders land are often quite significant. This is part of the generally high transaction costs associated with providing credit to small producers. In informal credit markets, close familiarity and social control is used to select promising clients or projects. This is quite costly as the scope for effective supervision is limited. Furthermore, informal lenders have only limited scope to diversify covariate risks, and they typically do not provide much long term credit. Interest rates on informal loans are thus high. Thus, both limited availability of credit and high cost of borrowing of credit and high cost of borrowing would prevent those who do not have accumulated savings from acquiring land. 30

Credit market imperfections can thus offset small farmers' supervision cost advantage. For the case of Sudan, for example, yields for virtually all crops are lower for poor (small) farmers and higher for rich (large) farmers, thus turning the farm-size productivity relationship upside down. Furthermore, the land rental market leads to land transfers from poor and labor-abundant small holders, to rich and relatively labor scarce households (Kevane 1996). The reason is that capital market imperfections combined with reasonably functioning land and labor markets and a technology that is not supervision intensive make it more attractive for small credit-constrained households to rent out land and work for a wage than to engage in owner-cultivation without capital inputs. By contrast, in panel data from Burkina Faso an inverse farm size-productivity relationship was observed even though a positive presence of correlation between yields and cash inflows from non-agricultural employment suggests the presence of capital market imperfections (Udry 1996). The conclusion is that imperfections in land, labor, credit, and

\footnotetext{
${ }^{29}$ Due to the covariance of production risks, crop insurance is very difficult and forward markets to insure against price risk are often unavailable to small producers due to high transaction costs.

${ }^{311}$ The difficulty of land acquisition through borrowing by would-be smallholders, in spite of their productivity advantage, has been highlighted by Binswanger and Elgin (1998) and Carter and Mesbah (1995). Furthermore, they point out that by exhausting access to credit for land acquisition, the ability to borrow for working capital is eliminated.
} 
insurance markets have to be analyzed together. Efforts at land redistribution that do not simultaneously address credit market imperfections may be costly and ineffective.

Portfolio composition: Small producers' inability to access formal markets for credit and insurance often forces them to adopt costly insurance substitutes, one of which is the adjustment of crop and asset portfolios to a low return -low risk combination. 31 In order to ensure satisfaction of a minimum subsistence requirement during periods of distress, credit-constrained producers could hold a portfolio of less risky but also less productive assets than unconstrained producers. In particular, small holders may demonstrate a lower demand for land than that which would seem to be justified by their potential productive advantage. Zimmerman and Carter (1996) use parameters from Burkina Faso to show that, starting from an egalitarian distribution of land, production risk together with covariance of land prices, leads to successive concentration of land via sales from more productive small producers to relatively less productive large farmers. This illustrates that improving the functioning of land sales markets will not necessarily lead to better resource allocation if other markets' distortions are not tackled. 32

Transaction costs: A further factor that might prevent land markets from achieving a first-best allocation is the transaction cost associated with land sales and rentals. It has often been observed (see, for example, Balcazar 1993, Carter and Zegarra, 1995) that, especially in countries with a dualistic distribution of land ownership, land sales markets are highly segmented in the sense that, despite a considerable frequency of land transactions within farm size groups, land sales across farm-size class-boundaries are virtually absent. One explanation is that transaction cost entailed in subdividing farms so as to enable to a multitude of small holders is high. Similarly, the fact that certain costs (e.g. formal registration) associated with land transactions are independent of the size of the purchase creates indivisibilities that would either discourage small land transactions or drive them into informality where such costs are not incurred.

While the discussion of costs associated with land rentals in the literature is less extensive, government regulations appear to have reduced the amount of land leasing below what would take place otherwise. Even in countries that avoided the imposition of explicit restrictions on tenancy, which (as discussed below) were associated with significant efficiency losses, the threat of expropriative land reform in many countries implied that renting out land to more productive smaller producers exposed the landlord to a considerable risk of losing ownership rights in the course of land reform. To prevent this from happening, many landlords

\footnotetext{
${ }^{31}$ Examples are provided by Rosenzweig and Wolpin (1995), Dercon (1996), Dercon and Krishnan (1996), and Rosenzweig and Binswanger (1993).

32 The fact that study of land markets can not be divorced from the functioning of other markets has beenemphasize by Basu (1986) in a model of "interim" land transactions which explicitly serve as a credit substitute. In this context, the supply of land for sale would increases with the probability of being able to buy back the land, the attractiveness of other (financial) assets as compared to land, and the need for liquidity. Sengupta (1997) draws out the implications of limited liability on contract choice within a more general set of contractual options.
} 
appear to have evicted tenants altogether, resorting instead to mechanization, cattle ranching, or cultivation using a hired labor force (de Janvry and Sadoulet, 1993). The implications for land rentals, although they have not been rigorously quantified in any of the cases, appear to have been considerable.

\subsection{LAND SALES MARKETS}

The discussion of the previous section implies that credit market imperfections tend to cause the equilibrium price of land to be above the capitalized value of the income stream that can be generated by an individual who has to rely on full mortgage-based land acquisition. In addition, policy distortions will tend to increase the wedge between the price of land and the capitalized value of the income from agricultural production. Use of land as an inflation hedge, as well as credit subsidies and tax advantages that allow the use agricultural activities as a tax shelter are examples (Gunjal et al. 1996; Brandao and Rezende 1992; Just and Miranowski 1989; Feldstein 1980). To the degree that such distortions confer disproportionate benefits to larger landholders (as in the case of tax advantages which are generally of no relevance to the poor), this would further bias the operation of the land sales market against redistributing land to landless or marginal landowning households who could have a productivity advantage as family farmers.

Analysis of land market transactions and offer and asking prices in Paraguay indicates the presence of a large gap between willingness to sell and willingness to pay, 33 significant differences in such prices across farm sizes, and very distinct regional patterns of land market performance depending whether or not other markets exist and how well they function (Carter and Zegarra 1996). Both reported and actual sales prices are downward sloping over the 1-40 hectare range (indicating superior productivity of small farmers) in traditionally settled zones in the country's interior, but not at the frontier where the labor cost advantage of family farms was overshadowed by capital market imperfections. Simulations using regression parameters suggest that the productivity advantage of small farmers would manifest itself in the land purchase market only if land market reform was combined with improved access to capital markets. A similar conclusion is implied by the observation that the degree to which financial markets were accessible to small producers was (together with the initial distribution of assets and the characteristics of the production system) one of the key factors that determined the response of land accumulation patterns to agro-export booms in Guatemala and Chile (Carter and Barham 1996).

\footnotetext{
${ }^{33}$ Willingness to sell was significantly higher than was willing to pay to purchase land but the gap decreases with farm size (from $50 \%$ for the smallest farms to $20 \%$ for medium sized units). This could be in indication for labor market imperfections, i.e. the value given to land as a source for self-employment, in addition to small farmers' unwillingness to be bought out.
} 
Exposure to undiversifiable residual risk causes farmers to resort to liquidation of their assets during periods of severe crisis, a phenomenon commonly referred to as distress sales. This is implies that the covariance of weather risks for the farming population causes land prices to be low (due to insignificant effective demand and high supply) during bad crop years, with the consequence that individuals who had to sell off land during crises may not be able to repurchase land during subsequent periods of recovery (Bidinger et al. 1994). Distress sales have not only played a major role historically in shaping more concentrated land ownership patterns, but are also linked to the elimination of traditional mechanisms for coping with risk in the literature (Kranton and Swamy 1997; Brockett 1984) ${ }^{34}$

The link between unmitigated production risk and distress sales is highlighted by Cain (1981) who examines the implications of different insurance mechanisms on distress sales and the land ownership distribution between 1960 to 1980 for predominantly agricultural villages in India and Bangladesh. These villages faced very high production risks but were characterized by distinct differences in mechanisms of risk-insurance: In Maharashtra, India, an employment guarantee scheme operated throughout the period and attained participation rates of up to 97 percent of all households during disasters. Such schemes were absent after the major flood episodes in Bangladesh. Thus, 60 percent of land sales in Bangladesh were undertaken to obtain food and medicine, undoubtedly due at least in part to the lack of other insurance mechanisms. About 60 percent of the currently landless had lost their land since 1960 and the Gini coefficient of landownership distribution increased from 0.6 to almost 0.7 . This contrasts sharply with the Indian villages, where land sales to finance consumption expenditures accounted only for 14 percent of sales and were incurred mainly by the rich to meet social obligations. On the other hand, 64 percent of land sales were undertaken in order to generate capital for productive investment (digging of wells, purchase of pump sets, and children's education), and the land sales market actually contributed to a slight equalization of the land-ownership distribution. This suggests that in this case the poor were not only able to avoid distress sales, but were able, through access to cash-generating employment, to acquire some land as rich households liquidated agricultural assets to be able to pursue non-agricultural investment. Survey data on land transactions from India indicate that purchases of land are almost all undertaken by individuals with access to sources of income which are not correlated with agricultural production and that borrowing to finance agricultural land acquisition is virtually non-existent (Sarap 1995).

\footnotetext{
${ }^{34}$ Distress sales have been important in China (Shih 1992) in early Japan (Takekoshi 1967) in the Indian Punjab (Hamid 1983), and in Latin . America following the abolition of communal tenure (Brockett 1984).
} 


\subsection{LAND RENTAL MARKETS}

As the discussion above illustrated, land sales markets will not necessarily lead to an optimal allocation of land in the presence of credit and insurance market imperfections. However, improved resource allocation can be achieved through land tenancy contracts even when other markets are incomplete. Analysis shows clearly that land rental markets serve an important function in equalizing returns to non-tradable factors of production such as family labor and bullocks (Skoufias 1991). 35 Given the huge diversity of tenancy arrangements, we need first to explain the wide range of tenancy contracts that is empirically observed in developing countries. This gives rise to the second issue, namely to investigate in more detail the implications of these contracts for the efficiency of resource allocation.

Assume a constant returns to scale production function $Q=\theta F(e, h)$ where $Q$ is output, e is effort, $h$ is number of tenants, and $\theta$ is a stochastic element. Then the range of contracts can be summarized as follows. The landlord's income is $y=h[(1-\alpha) Q-\beta]$, and the representative tenant's income is $Y=\alpha Q+\beta$. The fixed rent contract is given by $\{\alpha=1, \beta<0\}$, the pure wage contract is represented by $\{\alpha=0, \beta>0\}$; and the share contract is given by $\{0<\alpha<1\}$, with the sign and magnitude of $\beta$ a function of the landlord's choice of $\alpha$ and the tenant's reservation utility level (Otsuka et al. 1992).

Under conditions of certainty and the assumption that tenants' effort can be monitored and enforced, the specific choice of contract type does not matter as all contracts lead to equivalent outcomes (Cheung 1969). If the assumption of perfect effort enforceability is dropped, and under conditions of certainty (or equivalently, risk neutrality), only the fixed rent contract is optimal because in all other cases tenants receive only a fraction of their marginal product, which would induce them to exert less than the optimal amount of effort (where the marginal disutility is equal to the full marginal benefit from this action). Any type of contract other than fixed rent would result in undersupply of effort by the producer (tenant or worker), which would lower total production.

Indeed, fixed-rent tenancy is widespread in all developed countries such as the US and Canada, where about one third of the agricultural land is cultivated by tenants. The fact that virtually all of this land is rented under fixed term contract suggests that such an arrangement would be a relatively efficient way of achieving optimal operational holding sizes in economies with well functioning credit, risk, and labor markets. However, where markets for credit and insurance are highly incomplete and where the rural landless class is large, as is the case in most developing countries, adoption of a fixed rent contract where rent is paid up-

\footnotetext{
${ }^{35}$ Land rental transactions to circumvent imperfections in credit markets have been important in West Africa in the past (Robertson 1982), and continue to be observed in a number of developing countries where credit markets are absent or credit is highly rationed. Usufruct mortgage is
} 
front (or -equivalently- independent of the output of production) may not be feasible or optimal from the perspective of all parties to the transaction.

In such a situation, two main reasons, risk sharing and limited tenant wealth, could mitigate against adoption of the fixed rent contract and in favor of a sharecropping contract. 36 Although it would reduce the incentive to exert effort, a share contract provides the possibility of partly insuring a risk-averse tenant against fluctuations in output. Where, in risky environments, a risk-averse tenant faces significant uninsured risk, a share contract may well provide the tenant with higher expected utility and thus be adopted despite the lower aggregate productivity involved. In fact, it can be shown that in this case, the Pareto optimal outcome will always require a trade-off between the risk-reducing properties of the fixed-wage contract, under which the tenant's residual risk is zero, and the incentive effects of the fixed-rent contract, which would result in optimal effort supply but no insurance (Otsuka et al.). Given risk aversion and incomplete intertemporal markets, a one-period contract is a second-best solution. Part of this shortcoming can be eliminated by statecontingent side payments in the context of a repeated game 37

Limited tenant wealth increases the landlord's risk when a fixed-rent contract does not involve a front-end payment. In case of a disaster (such as a bad climatic shock) tenants with insufficient wealth are likely to default on the rent payment, implying that landlords will tend to enter into fixed rent contracts only with tenants who are wealthy enough to pay the rent under all possible output realizations. If tenants are poor, it will be optimal for the landlord to chose a share rather than a fixed rent contract (Shetty 1988). In a one period game this would imply that landlords would rank tenants by wealth, choosing to enter into contract only with the wealthiest tenants. Empirical evidence reported by Quibria and Rashid (1986) confirms such behavior. By implication, the efficiency of any particular tenancy contract is increasing in tenant wealth and the overall efficiency of the tenancy market would depend on the initial wealth distribution of potential tenants, generating a direct mapping between the distribution of wealth and economic efficiency (Bardhan et al. 1997). In a repeated game, landlords would allow all but the least wealthy tenants to earn positive profits in equilibrium, thus using the threat of contract termination (or eviction) as a device to elicit effort supply.

An extension of this argument is provided by Mookherjee (1997), who shows that in the context of bargaining on the terms of an interlinked tenancy contract between landlord and tenant the efficiency of

still reported to be common in Bangladesh (Cain 1981), Java (Morooka and Hayami 1986), and Thailand (Fujimoto 1988). In the Philippines, tenancy transactions emerged as a credit substitute in response to limitations on the transferability of land (Nagarajan and associates, 1991).

${ }^{36}$ A third rationale for adoption of the share contract, namely that imperfect information on tenants' unobservable characteristics such as ability, causes landlords to use sharecropping contracts as a screening device where the tenants' acceptance of certain types of contracts provides a signal for their productive ability (Newbery and Stiglitz 1979) does, at least for Indian data, not conform well with the data (Olson-Lanjouw 1995). 
the contract, i.e. the amount of effort exerted, will always be higher under operator-ownership of the land than under tenant-landlord relationship. 38 This would imply that redistribution of land from the landlord to the tenant - or any other measure (e.g. increased off-farm opportunities) that would increase the tenant's reservation utility - would be associated with an increase in aggregate productivity. Still, while such a redistribution could increase the aggregate utility of both parties (thus making compensation of the landlord a theoretical possibility), a voluntary market-based transfer of land from the landlord to the farmer is not feasible. The intuition is simple - since a credit-based land purchase does not enhance the tenants' wealth, the limited liability constraint will still be applicable and the debt overhang incurred by the cultivator to purchase the land will reduce the incentive to apply effort instead of just defaulting on the loan. However, a non-market transfer of land from landlords to farmers could be associated with an increase in overall productivity as well as aggregate welfare.

Insights on the relationship between liquid assets and contractual parameters are provided by Laffont and Matoussi (1994). Their results suggest that direct dependence of the optimal choice of contract on the working capital available to both landlord and tenant may account for the coexistence of a variety of contracts in the same environment among parties with roughly similar risk aversion but different endowments of working capital. 39 The positive relation between the crop share and the tenant's working capital endowment which theory would lead one to expect even with perfect monitoring of effort is indeed observed in the Tunisian data used. Output is shown to increases significantly with tenants' wealth for all contract types as well as for share contracts but tenant wealth has no effect if only fixed rent contracts are considered. Similarly, the wealth of the landlord has, as expected, a negative effect on the tenant's share and a positive effect on production under the share contract but none in other forms of contractual arrangements. Working capital thus appears to be a significant explanation of the type of contract chosen and the production gains achieved on a given plot.

The importance of potential tenants' asset endowment is emphasized by evidence from India which indicates that, due to wealth constraints, a large number of potential tenants is actually rationed out of the tenancy market (Shaban 1991). In this context, both the smallest and the largest landholders rent their land to middle farmers who are neither capital-constrained nor suffering from the disadvantage associated with the need to supervise hired labor. This illustrates that the ability of the land rental market to bring

\footnotetext{
${ }^{37}$ Sadoulet et al. (1997 and 1994) observe that close kin provide insurance to their tenants and are therefore able to avoid the inefficiency of the share contract.

${ }^{34}$ The scope for other benefits from a more egalitarian distribution of land ownership that are not directly related to agricultural productivity is illustrated by Banerjee et al. 1997.

3" If risk were a major factor in choosing the optimal type of contract, one would observe significant variation in crop shares according to the riskiness of the crops grown on particular plots. This is, however, not observed empirically.
} 
about efficiency-enhancing transfers is constrained by potential tenants' endowment of assets and other means of production (bullocks).

Thus, while land rental markets improve the allocation of resources in the presence of factor market distortions by bringing land to imperfectly or non-tradable factors of production (experience, family labor, animal power), the gains are constrained by endowments of potential transactors. In addition, there is evidence of fixed transaction costs which preclude some poor households that would desire only relatively minor adjustments, from entering the tenancy market. Similarly, data from India suggest the prevalence of imperfect adjustment whereby, on average, farmers realize only about $75 \%$ of the desired level of land transactions (Skoufias 1995). The latter study also indicates that the adjustment effected by the land rental market is asymmetric for net in-renters and out-renters; consistent with the view that market power depends on relative scarcity of factors; in this environment of land scarcity, it is easier to rent out than to rent in.

What, then, are the magnitudes of the productivity effects that are brought about by the operation of land rental markets? A comparison can be performed between sharecropped and owned (or cash-rented) plots for the same household (in order to control for unobservable farmer attributes) allows to estimate the loss due to the second-best nature of sharecropping. Bell (1976) was the first to conduct such an analysis, finding that farmers indeed exert less effort on tenanted plots. Applying the same methodology, Shaban (1987) found that, on average, tenancy was associated with a 32 percent lower output; but the difference was only 16 percent once adjustments were made for differences in land quality. Inputs of family labor and draft animals were significantly lower on sharecropped plots than on owned parcels. No statistically significant differences in productivity were found between owned plots and plots rented on a fixed-rent basis, confirming that fixed-rent contracts induce higher productivity. Other studies yield results that point in the same direction (Sen 1981).

The productivity loss entailed in sharecropping can be reduced through close social relationships, as confirmed by Sadoulet et al. (1997). Their study compared the attributes of contracts with kin and nonkin, finding that non-kin sharecroppers use significantly less inputs and obtain less output. However, there is neither a disincentive effect nor a reduction in output for sharecropping among close kin. This suggests that embedding contractual arrangements in a long-term relationship offers considerable potential to attenuate the disincentives and productivity losses that are otherwise associated with sharecropping contracts. This evidence is in line with the comprehensive review of the literature by Otsuka et al. (1992) who found a large number of studies about equally split between efficiency and inefficiency of sharecropping contracts. Studies that did not find a disincentive effect of sharecropping 
were generally conducted in environments where such a contract was embedded in enduring family and patron-client relationships or where effort was easily monitored.

Even within households, imperfections in land and labor markets, together with the inability to commit, may prevent individuals from achieving an optimal allocation of productive factors. For plot level panel data from Burkina Faso, Udry (1995) finds that reallocation of factors from male to female controlled plots within the same household could increase output by $6 \%$ - less than half of the estimated output loss from imperfect allocation of productive factors at the village level $(13 \%)$, but still significant. One interpretation is that, by "renting" out land to their husband, women would risk losing these rights. In the absence of other assets that could be transferred from the husband to the wife to provide assurance, they fail to do so, despite the productivity increases that this might entail.

All this implies that, although land rental markets can not completely eliminate structural impediments and bring about a fully efficient allocation of land in an economy, they can go a long way in bringing the operational distribution of holdings closer to the optimum. However, in quite a few countries, the extent of land rental markets has been greatly diminished by large landowners reluctance to engage tenants due to concern for potential challenges to their property rights. Furthermore, rental markets' potential to increase overall welfare was not well understood by governments. Consequently, the static productivity loss entailed in sharecropping tended to induce interventions that have limited the extent of rental transactions, thus causing a larger inefficiency in resource allocation. We turn now to discuss these and other policy issues related to land markets.

\section{POLICY ISSUES}

This section draws the main policy conclusions from our earlier discussion, focusing on clarification and adjudication of property rights, ways to improve the functioning of land sales and rental markets, and redistributive land reform. These three steps form somewhat of a sequence, in the sense that it is difficult to improve the functioning land sales or rental markets without clarification of land use and ownership rights, or to conduct non-expropriative land reform in an environment where land markets are absent. This implies that government activity should be focused on eliminating distortions and taking measures to reduce market imperfections rather than attempting to compensate for imperfections and distortions in other markets. 


\subsection{ClaRIfICATION AND ADJUdiCATION OF PROPERTY RIGHTS}

A coherent system of property rights that guarantees security of tenure to cultivators, facilitates access to land by the poor, and encourages investment to increase sustainability and productivity, is of overriding policy importance in two types of settings. In countries making the transition from communal to more individualized forms of land ownership, there is need for a flexible, stepwise, and decentralized approach that acknowledges differences in demand for tenure security based on diversity across regions and agroclimatic conditions. This implies the need for a legal framework that permits evolution of land rights towards individualized tenure as the need emerges with commercialization and land scarcity. Second, in situations where land tenure arrangements have been severely disrupted either by civil strife and war, by collectivist land reform, or by land-grabbing of influential individuals (e.g. Bolivia, Honduras, Nicaragua, Cuba, Vietnam, Ethiopia, Uganda, Tanzania, and the FSU), an approach that adjudicates among overlapping claims and establishes clear ownership rights to land at minimum cost is needed.

The evidence reviewed in preceding sections demonstrates that secure land rights are crucial for longer-term investment and the associated productivity increases. Land registration and titling systems are often perceived as an important element in a policy seeking to promote tenure security and to facilitate more effective land markets. This is because official documentation provides better protection to an owner's property rights, and eliminates the asymmetric information that curtails land markets transactions. However, experience with titling programs has shown that in sparsely populated areas the cost of introducing formal titling systems may outweigh the benefits and that the administrative infrastructure needed to effectively implement such rights was not available. Similarly, formal documentation is not crucial where customary tenure systems provide sufficient security to facilitate the level of investments and land transactions that are relevant for the prevailing economic environment, and where credit markets are not yet developed to the point where collateral use is necessary.

Past interventions have often underestimated the cost and administrative requirements of providing tenure security through formal title and have given little thought to the scope for alternative means to provide such security. Community-based approaches whereby a whole area is demarcated and internal administration of land rights (including provision of documentation by local authorities) is left to the community may in many cases provide a cheaper alternative to formal titles (Platteau 1992). However, the critical precondition for such an approach to work is that consistent implementation of this arrangement is feasible, that decentralized institutions are accountable and effective, and that the certificates awarded by such authorities are legally recognized, entailing a possibility of converting them into more formal titles at a later stage. 
The 1992 modification of the Mexican Constitution, and similar arrangements in a number of other countries (e.g. Bolivia, Colombia, Cote d'Ivoire, and Nicaragua), allow indigenous and non-indigenous communities to administer property rights internally. In the case of Mexico this also includes communities' right to decide, subject to established rules of accountability, on the partial or formal transformation of their land rights into individual freehold title (Gordillo et al. 1997). In principle, such an arrangement would allow the utilization of informational advantages available at the community level to tailor property rights to the specific situation at hand. However, little is known about the transaction costs incurred and the degree to which outcomes have been equitable and conducive to improved efficiency. Evaluation of these experiences within a consistent framework would be very desirable and could provide valuable insights to fine-tune the approach and make the experience useful for other countries.

The benefits associated with individuals' ability to use title to gain access to formal credit have been discussed above. Experience shows that titling programs are most effective in areas where tenure insecurity already affects incentives, where there is an incipient formal credit market where title can be used as a collateral because foreclosure of collateral is enforceable, and where an effective legal system operates. 40 It is important to include safeguards against the grabbing of land (and in particular of hitherto common land) by powerful and wealthy individuals, who are typically better informed on the procedures entailed in more formal systems (Feder and Nishio, 1998).

Past experience also suggests that land titling should be systematic and area-based rather than "on demand".41 An area-based program with complete coverage can utilize economies of scale in measurement, adjudication, and a speedy process for conflict resolution. This would reduce the cost of program implementation. Experience in Thailand, El Salvador, Peru, and Bolivia, among others, demonstrates that this can be accomplished by introducing titling in combination with a mechanism for dispute resolution on location (within the community) and a comprehensive publicity campaign. ${ }^{42}$ In contrast, "on demand titling" is not only costly, but is often very inequitable. It provides individuals with good political connections- opportunities for land grabbing and precludes poor smallholders from participation due to the high cost of land registration.

\footnotetext{
I" The example of Kenya, where banks could not foreclose on the land that had been given to them as collateral because of social and ethnic factors illustrates that -even where there is a demand for formal credit and the use of land as collateral- it is only the ability to effectively foreciose on defaulters that will persuade banks to accept land as a collateral for loans (Ensminger 1997).

${ }^{+1}$ Given the fixed cost element entailed in "on demand" titling (which is based on individual initiative) and the lack of economies of scale, this format of titling will tend to be more accessible to the wealthier landowner.

+2 This would be of particular importance in the case of Africa where resistance against titling is fueled more by the fact that generally individualization of land tenure has been associated with extreme land grabbing by powerful individuals - much more than the activation of a land sales market that would disempower smallholders (Bruce, 1993).
} 


\subsection{IMPROVING THE FUNCTIONING OF LAND SALES AND RENTAL MARKETS}

Land sales markets: The fear of the undesirable consequences associated with land market operation in an environment characterized by market imperfections seem to have in the past motivated policy-makers to impose restrictions on the operation of such markets. We have argued above that in the presence of multiple market imperfections and policy-induced distortions, reducing the transaction costs associated with land sales or taking other measures (e.g. elimination of the threat of expropriation due to renting out) that would improve the functioning of land markets will not necessarily enhance the efficiency of land allocation. Administrative restrictions on land sales have, however, generally proven to be costly to enforce and were often ineffective in preventing outcomes that were undesirable from an equity perspective.

Administrative restrictions on land sales typically take the two main forms of limits on tradability of land and ownership ceilings. In many cases beneficiaries of land reform or settlers on state-owned land are not allowed to sell or mortgage their land. This would deprive them from accessing credit - often in the establishment phase when credit would be most needed. It has been shown that, in the presence of such restrictions, small-holders are forced to resort to less efficient arrangements (e.g. usufruct-mortgaging and the associated use of wage labor contracts) to gain access to credit (Hayami and Otsuka 1993). The desirable goal of preventing land reform beneficiaries from selling out in response to temporary shocks would be better served by adequate training and preparation, as well as ensuring that they have access to the resources and know-how necessary to establish productive investments, and in complementary reforms of credit markets and institutions (e.g., liberalizing interest rates). Permanently precluding land reform beneficiaries from rental or sales is likely to reduce efficiency-by permitting the existence of large tracts of uncultivated or less than optimally utilized land reform land; allowing for some adjustments in response to differential settler ability may be preferable to the losses imposed by this measure.

Another restriction intended to facilitate the breakup of large farms and the associated sales of land to small producers has been the imposition of land ownership ceilings, often together with land taxes. Although little rigorous evidence concerning the impact of such ceiling laws exists, they appear to have imposed extra cost on landowners who often took measures to avoid them and on the bureaucracy which had to decide on exceptions to allow for the utilization of economies of scale in plantation crops - a process conducive to red tape and corruption. Even in the most favorable case such ceilings would constitute a temporary second best measure to allow government to deal with the problem in a more thorough way. If, as suggested by the evidence, the reason for land concentration is not in a relative inefficiency of small farms but rather imperfections and policy-induced distortions in product and financial markets and the limitations on small farmers' ability to self-insure, it would be more effective for government to focus on the root of the problem 
rather than trying to deal with the symptoms. This implies that concerns about potential adverse equity impacts of land sales should be addressed by helping small farmers to compete, taking measures to improve the functioning of financial markets, and providing relief to avoid distress sales in cases of disaster.

Land taxation: A moderate land tax levied and collected by local Governments can make an important contribution to effective decentralization. The theoretical attractiveness of a land tax derives from two reasons. On the one hand, taxation of land is one of the few cases of a lump sum tax where -using asset rather than production values- the effective tax rate on income decreases with the income generated from the land, thus encouraging more productive resource use. On the other hand, a land tax is one of the few taxes that can provide revenues for the local governments, and that -through the capitalization of local amenities in land values- establishes a direct relationship between tax level and the benefits received by taxpayers (Glaeser 1995).

Several countries have attempted to implement progressive land taxes, where the tax rate would increase with land area or value, as a means to make land speculation less attractive and to induce large landowners to use their land more intensively or to break up large estates. Experience with this instrument has not been very positive as implementation and collection of progressive land taxes have been frustrated by political difficulties and resistance in countries as diverse as Argentina, Bangladesh, Brazil, Colombia, and Jamaica (Strasma et al. 1987; Bird 1974). Carter and Mesbah (1996) use simulations to show that a progressive land tax by itself is unlikely to be effective even if it is enforceable. Effectively collecting a uniform land tax may be a more realistic goal. However, in environments characterized by high risk, introduction of a land tax may not be desirable for equity reasons and a mix of land tax (which will have to be paid regardless of realized output) and output tax (contingent on realized output) Pareto-dominates either tax in isolation (Hoff 1991). To avoid negative equity consequences that might be associated with a land tax, a number of developing countries exempt small producers below a certain size from the need to pay land taxes.

Land rental markets: Their potential shortcomings notwithstanding, rental markets are more effective than sales markets in moving the distribution of operational holdings closer to the optimum. The analytical literature suggests that both the efficiency and the equity impact of the land rental markets depend on tenants' bargaining power, i.e. their reservation utility. Mere prohibition of certain contractual forms that does not change the underlying forces and may lead to a worsened resource allocation by forcing market participants to resort even less efficient arrangements.

Rather than recognizing the potential of land rental markets to improve agricultural productivity and to augment the welfare of landless poor people, governments have often focused efforts on restricting tenancy 
markets through advised bans on share tenancy and limits on cash rental fees. From a theoretical point of view, the expected impact would be ambiguous. On the one hand, there is a negative direct effect as prohibition of tenant eviction precludes the landlord from using the threat of eviction as a device to elicit higher effort by the tenant and would therefore be expected to reduce productivity. On the other hand, the reallocation of bargaining power in favor of the tenant would increase incentives to supply effort and thus productivity. While one would expect the adverse incentive effect to dominate at low wealth levels, the positive effect would be dominant for farmers with intermediate wealth(Banerjeeand Ghatak, 1997).

Empirically, district level data from West Bengal suggest that effective implementation of tenancy registration which protected tenants from being evicted and fixed an upper ceiling for rent yielded significant productivity gains of about $40 \%$ - larger than the static loss estimated by Shaban (Banerjee and Ghatak, 1997). While this suggests that tenancy reforms can be effective, one should not forget that the study area is the only state in India where regulation of tenancy was actually implemented, that costs of implementation need to be considered in making an assessment of the economic benefits from such a measure, and that tenancy reform may not have been the only alternative available.

Regulatory interventions such as tenancy regulation lead to reduced investment incentives on the part of the landlord, while tenants may not perceive sufficient security to invest at what would be a socially optimal level. The trade-off between the positive effect of greater security to tenants and the investment incentives of owners is not easily balanced. Therefore, scarce financial and administrative resources might be better spent in efforts to foster general pro-poor development (e.g. education, infrastructure, credit and insurance, markets, and off-farm employment opportunities) that improve the bargaining position of would-be tenants, and that facilitate more fixed rent contracts, than in trying to enforce tenancy regulations. The difficulty of striking such a balance is illustrated by the fact that, in areas where tenancy was prohibited, wage labor (which is less conducive to productivity than tenancy or owneroperated farming due to lower effort by workers) is common, leading to inefficient factor substitution away from labor (Otsuka et al. 1993).

\subsection{REDISTRIBUTIVE LAND REFORM}

Our earlier discussion pointed out that unmitigated operation of land markets alone would not necessarily produce an optimal land allocation. In the land sales market, credit constraints would restrict the ability of the poor to acquire land (or any other indivisible asset), a phenomenon that has, in a more general context, been shown to be associated with intergenerational persistence of poverty (Banerjee and 
Newman 1991). 43 Transactions in the land rental market are easier to accomplish, but may be associated with a more limited impact on investment and productivity as well as tenant welfare. Efficiencyenhancing rental transactions might not come about either because of high transaction costs (especially in an unclear legal environment) or because of government restrictions that threaten rented properties with expropriation. In situations characterized by pervasive inequality in the ownership distribution of land or assets more generally, government involvement in redistributive land reform, aiming to improve efficiency and equity and at the same time remove impediments to the functioning of factor markets, could be justified.

However, historically the experience with government initiated land reform policies has been mixed, not only because reforms involving significant asset transfers are politically difficult and could be speedily implemented only where they were imposed by an outside power or a revolutionary change of regime. ${ }^{44}$ In the case of landlord estates where tenants already cultivated the land and all that was required was a reassignment of property rights, land reform was generally easy: The organization of production retained the same family farm system, where beneficiaries already had the skills and implements necessary to cultivate their fields. The administrative requirements associated with this type of land reform were minimal and considerable efficiency gains have often been realized, by improving incentives to work and invest by former tenants. 45 The magnitude of such gains was affected by the difference in (long- and short-term) incentives between the before- and after-reform situation. Where before the reform security of tenure and incentives to invest had already been high, cash-rent (rather than share rent) contracts had prevailed, and landlords had provided tenants with access to markets for credit, inputs, and outputs, one would expect the productivity gains from such reforms to be more modest. 46

By contrast to the generally successful experience in landlord estates, land reform in hacienda systems i.e. systems where tenants had a small house-plot for subsistence but worked for most of their time on the landlord's home farm, has been very difficult to accomplish. Thus some argued that the "game of Latin American Land Reform" has been lost (de Janvry and Sadoulet, 1989). In the large majority of these

\footnotetext{
43. This idea has been formalized in theoretical models where lack of collateral keeps individuals in "poverty traps", unable to undertake indivisible investments which would be highly profitable (Galor and Zeira 1993, Eckstein and Zilcha 1994; Jalan and Ravallion, 1996, Fafchamps and Pender 1996).I $n$ such a situation, a one-off asset distribution could be more effective than continuing redistributive efforts with the associated disincentive effects (Banerjee and Newman 1993).

+ The marked difference in the success of land reform between Korea, Taiwan, and Japan on the one side and Nicaragua, Cuba and Vietnam on the other suggests that the ability to redistribute large amounts of land is not a sufficient condition for land reform to be successful.

${ }^{45}$ Indeed, since the end of World War II, landlord estates in Bolivia, Eastern India, Ethiopia, Iran, Japan, Korea, and Taiwan have been transferred to tenants in the course of successful land reforms. While evidence on the productivity impact of such reforms is much less than what would be desirable, they have generally been associated with significant increases in output and/or productivity (King 1973Lieten 1996, Besley and Burgess 1998).

16 The degree to which land reform improved productivity and cultivator welfare increased with the profitability of existing investment opportunities (Callison 1983; Koo 1968; King 1973); the degree to which land ownership enabled the new owners' to access markets for credit and insurance that had previously been beyond their reach Domer and Thiesenhusen 1990), and the availability of new technology that could be readily adopted (Otsuka 1991).
} 
systems, large landowners responded to the threat of land reform by either evicting tenants who could have made claims to land ownership under a possible reform program, or converting them into wage laborers. In the case of eviction, landlords reduced reliance on hired workers either by resuming extensive livestock production and ranching or -aided by significant credit subsidies- by embarking on highly mechanized self-cultivation (Binswanger et al. 1995). This did not only reduce tenant welfare but also depopulated farms and created further difficulties for redistributive land reform. A number of further difficulties of effective land reform in hacienda systems are associated with policy distortions, limitations on the functioning of the land market, and inability to provide the necessary complementary elements for land reform beneficiaries to start successful small farm enterprises.

First, the cost of carrying out land reform were often increased by the continued existence of implicit and explicit policy distortions (e.g. agricultural protection and selective credit subsidies) which drove land prices above the capitalized value of agricultural profits and often disproportionately benefited large producers. Such distortions increased the fiscal cost of land reform policies and reduced their sustainability by making it profitable for land reform beneficiaries to sell their newly acquired land back to large farmers. Indeed, despite attempts to limit beneficiary desertion through imposition of legal restrictions and the threat of punishment in case of contravention, there is considerable anecdotal evidence on land sales by reform beneficiaries in Nicaragua, Colombia, and El Salvador. In a recent Census of Brazilian land reform settlements, only about $60 \%$ of recently established land reform beneficiaries were actually found tilling their land (El Globo 1997).

Secondly, many countries aimed to implement land reform by eliminating or restricting other forms of (rental and sales) market transactions. This completely eliminated price and other market signals, making it more difficult to select beneficiaries and land and further increased the costs of land reform implementation. It also tilted the balance in favor of a highly centralized mode of land reform implementation that has, in a number of countries, led to the domination of land reform processes by formidable (and often corrupt) centralized bureaucracies. In addition, and probably most important, this virtually eliminated beneficiaries' access to credit markets, despite the evidence that without access to such markets, it will be difficult for them to sustain themselves. In some cases, beneficiaries became worse off than they had been before, if a landlord provided them with inputs and possibly even credit for consumption smoothing. In Ireland, for example, a large scale experiment in "negotiated" land reform early in the $20^{\text {th }}$ century did not have the expected effect for two reasons. On the one hand it did little to alter the structure of production or to improve tenants' rights. More importantly, however, it actually worsened access to credit, by limiting the ability of 
new landowners to mortgage land while at the same time cutting off informal credit they had earlier obtained from the landlord (Guinnaune and Miller, 1997). 47

Thirdly, transforming a large farm into a viable smallholder enterprise requires a change in the pattern of production, subdivision of the farm, and construction of infrastructure. As the productivity advantage of land reform hinges on increased incentives by owner-operators and adoption of labor-intensive crops, attention to complementary investments and awareness by beneficiaries are critical. Generally beneficiaries, even if they are workers of the former farm, are not accustomed to making independent entrepreneurial decisions, implying that training and human capital formation is therefore an essential component of the land reform process. Realizing the productivity benefits from land reform requires to shift the focus from political to productivity- and poverty related objectives. 48

Due to these difficulties, and the fact that land reform was a highly politicized topic, many of the land reforms that have been undertaken since the 1960s have not achieved their stated objectives. Evidence on the longer-term impact of land reform on poverty and productivity is more limited than desirable. ${ }^{49}$ However, in countries (e.g. Zimbabwe, Malawi, South Africa, Brazil, Colombia, and the Philippines, among others) that continue to be characterized by concentration underutilized tracts of land in large farms alongside with pervasive lack of land access for poor and landless, macro-economic reforms have altered the rules of the game. The fall in land prices associated with the loss of privileges that had historically been conferred on large farms them by discriminatory laws, trade protection, and credit subsidies might make it easier to utilize the market for a type of land redistribution aimed at increasing productivity and equity.

To this end, a number of countries (Brazil, Colombia, South Africa) are in the process of implementing a new model of "negotiated" land reform. Key elements of this approach are (i) an emphasis on sustainable poverty reduction through elaboration of integrated farm projects by the poor (which are then supported by a land purchase grant); (ii) decentralized execution and integration into development objectives at the local level with an overarching emphasis on beneficiary training and human capital formation; (iii) and private sector involvement in project development, financing, and implementation. Obviously, mere adoption of a "negotiated" mode is not immune against the shortcomings that have plagued earlier land reform

\footnotetext{
${ }^{47}$ Severely restricted access to credit, together with insecure property rights have also led to widespread selling of land by former land reform beneficiaries in Nicaragua - often at prices way below the productive value of the land (Joakin 1996).

${ }^{+3}$ The effect of political motivation on beneficiary selection and the stop-and go cycle of land reform in response to political crises rather than opportunities for productivity increases and poverty reduction, and the difficulties of urban-basedelites to design reform programs to suit small farmers are well documented (Barraclough 1970).Apolitical approach to land reform would be consistent with the interpretation of land reform as a piecemeal strategy by the rich to avoid the imminent threat of revolt - with backtracking as soon as the threat weakens (forowitz 1993).

${ }^{+1}$ One example for such economic analysis is the study by Scott et al (1976) for Kenya. While it illustrates that land reform can have a positive social rate of return, it is based on data gathered in the immediate aftermath of the reforms after which data collection was discontinued.
} 
attempts. 50 Initial evidence from pilots that have aimed to integrate land reform into a more comprehensive package of support does, however, suggests that the new approach is perceived to be significantly different from earlier land reform attempts (Deininger, 1998). While this points towards a scope to reduce poverty and increases agricultural productivity and a positive social rate of return, the degree to which this potential is actually realized needs to be assessed through careful monitoring in the future.

\section{CONCLUSION: AREAS FOR FURTHER RESEARCH}

While research on land markets and land institutions has been extensive, there are a number of areas where additional or more conclusive knowledge would be of great value. Below we highlight a number of key areas that would merit further study.

\section{SECURITY OF LAND RIGHTS}

There is broad agreement in the literature that secure individual land rights will increase incentives to undertake productivity enhancing land-related investments. If there is scope for agricultural intensification, these rights can be enforced at low cost, and secondary rights to land by other stakeholders are not eliminated in the process, then establishment of such rights would constitute a clear Pareto improvement. However, in many cases, traditional systems are associated with a wide range of equity benefits not all of which can normally be preserved in a system characterized by private land ownership. Research aiming to understand not only the existence and magnitude of productivity benefits arising from the transition from traditional to private property rights, but also the types of welfare benefits provided by different forms of communal arrangements, their magnitude, and possible alternative mechanisms to generate similar effects, would be very useful. It could facilitate better identification of the point at which a transition from traditional to individualized tenure arrangements might be socially optimal and allow adoption of mechanisms that would ensure tenure security with minimal social disruption. Evaluation of country cases where innovative ways to make this transition have been explored recently could be a starting point for such an endeavor.

\section{LAND MARKETS}

While there has been significant research on the static inefficiency of tenancy contracts, the welfare consequences and the impact of tenancy on farmers' investment behavior have received less attention.

\footnotetext{
${ }^{50}$ Due to a lack of poverty targeting, an exclusive focus on land purchases but not complementary investments, and a high (75\%) level of subsidy, a "negotiated" program of land reform that was carried out in Italy during the 1948 to 1970 period had only a limited impact on poverty reduction and was characterized by relatively high costs (Shearer and Barbero 1993).
} 
Assessment of the welfare aspects of tenancy, i.e. the impact of land ownership as compared to mere usufructuary rights on household well-being would be of relevance to help policy-makers determine specific steps for comprehensive land market development. Such analysis should consider the impact of access to land under different systems on productivity and welfare (e.g. through choice of livelihood strategies, higher or more smooth consumption, access to credit, ability to accumulate wealth, etc.).

A large body of literature on land price formation, and the relationship between land sales and rental prices exists in developed countries (see Just and Miranowski in this volume). However, much less is known on this issue in developing countries, in particular how recent dramatic changes in macroeconomic policy have affected land values and the relationship between land prices and agricultural profits. Elimination of credit subsidies and tax privileges, changes in relative prices of different types of agricultural products, and increased attractiveness of non-land financial assets that have been associated with these policies would have important implications not only for land prices but also for the operation of land (sales and rental) markets. This would also affect the type of economic agents who would be able to use these markets to gain access to land and the type of complementary policies (e.g. in the area of credit) that would affect their ability to do so.

Notwithstanding the fact that markets are an important avenue for individuals to gain access to land, nonmarket transactions such as inheritance, allocation by village chiefs, informal rentals among kin, and use of on common property resources for collection and gathering continue to have a far-reaching impact on a large part of the population and the structure of land ownership and land use in many parts of the world. A large descriptive literature discusses advantages and disadvantages of non-market mechanisms. However, quantitative evidence on the efficiency and equity impact of non-market transactions and the way in which policies that aim to change decision-makers' incentive affect the extent and modalities of such transactions is still limited. Given that informal systems tend to be characterized by lower transaction costs and can provide land access for the poorest segments of the population who may not be able to utilize land rental and sales markets, better understanding of the potentials and shortcomings of non-market mechanisms would be of great interest. There is also little doubt that in situations where, either traditionally or due to male out-migration, a significant part of agricultural production activities is carried out by women, the nature of womens' land rights -many of which are defined informally- will have far-reaching implications for agricultural productivity and investment. However, much remains to be learned about the interaction between legal prescriptions, social norms, and intra-household bargaining in determining the nature of womens' rights to land, and the scope for specific policy interventions to bring about efficiency increases by strengthening these rights. 
Over and above the market imperfections characteristic of rural areas, functioning of land rental and sales markets has, in the past, often been constrained by government interventions - in many cases with the aim to promote equity or overcome market imperfections. While the effectiveness of such policies was often limited, they generally left an institutional legacy that is difficult to dismantle. Research on the links between land and other markets could do much to identify such "second generation reforms" and to facilitate their implementation in an environment characterized by multiple market imperfections.

\section{LAND REDISTRIBUTION}

Compared to the volume of resources that has, since the $1960 \mathrm{~s}$, been spent on land reform programs, the effort invested to monitor their performance and assess their impact on poverty reduction and agricultural productivity was minuscule. As a consequence, evidence on promising models of land reform in haciendas and the long-term impact associated with them is extremely limited. Little or no guidance exists to compare the effectiveness of different approaches to land reform in (i) reaching specific target groups; (ii) in helping these groups to complement land ownership with other investments and thereby increase agricultural productivity; and (iii) enabling them to convert the one-time transfer of land into a sustained improvement in their livelihood. Such evidence will be critical to assess whether these new approaches to market assisted land reform are fiscally, socially, and economically sustainable.

Given the recent emphasis in the theoretical literature on asset ownership as a means for sustainable poverty reduction, it would be of great interest to carefully monitor innovative land reform efforts with a view toward drawing the necessary policy-conclusions. Issues to be explored include the volume and price of land (sales and rental) transactions, characteristics of participants, and the productivity change associated with land transactions within and outside a specific land reform program. Complementing this with longitudinal information on changes in welfare of specific beneficiaries and the population at large would provide an opportunity to assess the equity impact of land reform and ultimately compare this type of intervention to other policies aimed at the same goal. 


\section{References:}

Allen, D.W. 1991. "Homesteading And Property Rights; Or, 'How The West Was Really Won'." Journal of Law and Economics, 34, pp. 1-23.

Alston, Lee J., Gary D. Libecap and Robert Schneider (1995) 'Property Rights and the Preconditions for Markets: The Case of the Amazon Frontier', Journal of Institutional and Theoretical Economics, 151/1: 89-111.

Alston, Lee J., Gary D. Libecap and Robert Schneider. (1996) 'The Determinants and Impact of Property Rights: Land Titles on the Brazilian Frontier', Journal of Law, Economics, \& Organization, 12/1:25-61. Oxford: Oxford University Press.

Andre, Catherine and Platteau, Jean-Philippe. (1996) 'Land relations under unbearable stress: Rwand caught in the malthusian trap', Namur, Belgium: Centre de Recherche en Economie du Development (CRED).

Atwood, D.A. (1990) 'Land registration in Africa: the impact on agricultural production', World Development, 18: 659-671.

Auty, Richard M. (1997), Natural resource endowment, the state and development strategy, Journal of International Development 9:651-63.

Baland, Jean-Marie and Jean-Philippe Platteau. (1997) 'Wealth inequality and efficiency in the commons. Part I: The unregulated case.', Oxford Economic Papers, 49: 451-482, Oxford: Oxford University Press.

Baland,-Jean-Marie; Platteau,-Jean-Philippe, Coordination Problems in Local-Level Resource Management, Journal-ofDevelopment-Economics;53(1), June 1997, pages 197-210.

Baland,-Jean-Marie; Platteau,-Jean-Philippe, Halting degradation of natural resources: Is there a role for rural communities? Oxford University Press, Clarendon Press, 1996

Baland,-Jean-Marie; Platteau,-Jean-Philippe, Wealth Inequality and Efficiency in the Commons, Part II: The Regulated Case , Oxford-Economic-Papers;50(1), January 1998, pages 1-22..

Balcazar, Alvaro. (1990) 'Tana 70 de finca, dinamica tecnologia y rendimientos agricolas', Coyuntura Agropecuaria, 7/3:107125 .

Banaerjee, Abhijit V., and Ghatak, Maitreesh. (1996) 'Empowerment and efficiency: the economics of tenancy reform', Massachusetts Institute of Technology.

Banarjee, Abhijit V. and Newman, Andrew F. (1993) 'Occupational choice and the process of development', Journal of Political Economy, 101/2: 274-298, Chicago: The University of Chicago.

Banerjee, Abhijit V. and Andrew F. Newman. (1991) 'Risk-bearing and the theory of income distribution', Review of Economic Studies, 58:211-235.

Banerjee, Abhijit, Dilip Mookherjee, Kaivan Munshi and Debraj Ray. (1997) 'Inequality, control rights and rent seeking: a theoretical and empirical analysis of sugar cooperatives in Maharashtra', Boston University.

Bardham, Pranab, Samuel Bowles and Herbert Gintis. (1997) 'Wealth inequality, wealth constraints and economic performance', University of Massachusetts, Amherst.

Barham, Bradford L., Stephen Boucher and Michael R. Carter. (1996) 'Credit constraints, credit unions, and small-scale producers in Guatemala', World Development, 24/5:793-806.

Barham, Bradford, Michael R. Carter and Wayne Sigelko. (1995) 'Agro-export production and peasant land access: Examining the dynamic between adoption and accumulation', Journal of Development Economics, 46: 85-107.

Barraclough, S.L. (1970) "Agricultural Policy And Land Reform.” Journal of Political Economy : pp. 906-947.

Barrett, Christopher B. (1996) 'On price risk and the inverse farm size-productivity relationship', Journal of Development Economics, 51:194-215.

Baruah, Sanjib. (1990) 'The end of the road in land reform? Limits to redistribution in West Bengal', Development and Change, 21:119-146.

Basu, Kaushik (1986), Market for land; an analysis of interim transactions. Journal of Development Economics 20:163-77

Benjamin, Dwayne (1992) Household composition, labor markets, and labor demand: testing for separability in agricultural household models, Econometrica, 60:287-322. 
Benjamin, Dwayne. (1995) 'Can unobserved land quality explain the inverse productivity relationship?', Journal of Development Economics, 46:51-84.

Berry, R.A., and Cline, W.R. (1979) Agrarian structure and productivity in developing countries. Geneva: International Labor Organization.

Besley, T. and R.Burgess (1998), Land Reform, Poverty Reduction, and Growth: Evidence from India, LSE mimeo

Besley, Timothy. (1995) 'Property rights and investment incentives: Theory and evidence from Ghana', 103/5: 903-937, University of Chicago.

Bhalla, S.S., and Roy, P. (1988) 'Mis-specification in farm productivity analysis: the role of land quality, Oxford Economic Papers, 40:55-73.

Bidinger, P.D., Walker, T.S., Sarkar, B., Murty, A.R., and Babu, P. (1991) 'Consequences of mid-1980s drought: longitudinal evidence from Mahbubnagar', Economic and Political Weekly, 26:A105-A114.

Binswanger, H.P., and Elgin M. (1988) 'What are the prospects for land reform', in: Maunder, A., and Valdes, A. eds, Agriculiure and governments in an interdependent world. Proceedings of the Twentieth International Conference of Agricultural Economists, 1988.

Binswanger, H.P., and Rosenzweig, M.R. (1986), 'Behavioral and material determinants of production relations in agriculture', Joumal of Development Studies, 22:503-539

Binswanger, Hans P., Klaus Deininger and Gershon Feder (1995). "Power, Distortions, Revolt And Reform In Agricultural Land Relations." Handbook of Development Economics, Volume III. Jere Behrman and T.N. Srinivasan, eds.

Binswanger,-Hans-P.; Deininger,-Klaus 1997, Explaining Agricultural and Agrarian Policies in Developing Countries, Journal of Economic Literature 35(4), December 1997, pages 1958-2005

Bird, R. (1974) Taxing agricultural land in developing countries. Cambridge, Massachusetts, Harvard University Press.

Birdsall, Nancy and Londol $\square$ o, Juan Luis. (1997) 'Asset inequality matters: an assessment of the World Bank's approach to poverty reduction', AEA Papers and Proceedings, 87/2:32 -37, The World Bank.

Blarel, B., Hazell, P., Place, F., and Quiggin, J. (1992) 'The economics of farm fragmentation: evidence from Ghana and Rwanda', World Bank Economic Review, 6:233-254

Boserup, Ester. 1965. Conditions of Agricultural Growth: The Economics of Agrarian Change Under Population Pressure. New York: Aldine Publishing Co.

Bowles, Samuel and Gintis, Herbert. (1994) 'Escaping the efficiency-equity tradeoff: productivity enhancing asset redistributions,' Macroeconomic policy after the conservative era: Research on investment, savings, and finance, Cambridge: Cambridge University Press.

Brandao, A.S.P., and Rezende, G.C.de (1992) Credit subsidies, inflation and the land market in Brazil: a theoretical and empirical Analysis, Washington: World Bank, mimeo.

Brasselle, Anne-Sophie, Frederic Gaspart and Jean-Philippe Platteau. (1997) 'Land tenure security and investment incentives: some further puzzling evidence from Burkina Faso', CRED, Namur, Belgium.

Brockett, C.D. 1990. Land, Power, and Poverty. Agrarian Transformation and Political Conflict in Central America. Boston: Unwin Hyman.

Brooks, K. and Zvi Lerman (1994) Land reform and farm restructuring in Russia, World Bank Discussion Paper 233, Washington DC

Bruce, J.W. (1988) 'A perspective on indigenous land tenure systems and land concentration, in: Downs and Reyna, eds., Land and society in contemporary Africa.

Bruce, J.W. and Migot-Adholla, S. 1994, Searching for Land Tenure Security in Africa, Kendall Hunt Publishing Company, Dubuque, IA

Burgess, Robin. (1997) 'Land, welfare and efficiency in rural China', London School of Economics.

Cain, M. (1981) 'Risk and insurance: perspectives on fertility and agrarian change in India and Bangladesh', Population and Development Review, 7:435-474.

Callison, C.S. (1983) 'Land to the tiller in the Mekong Delta: economic, social and political of land reform in four villages of South Vietnam. Bloomington, $\mathbb{N}$, University Press of America. 
Calvo, Guillermo A. and S. Wellisz 1978. Supervision, loss of control, and the optimum size of the firm, Journal of Political Economy 86, 943-952. Chicago.

Carter, M.R., and Wiebe, K.D. (1990) 'Access to capital and its impact on agrarian structure and productivity in Kenya', American Journal of Agricultural Economics, 72:1146-1150.

Carter, Michael R. and Barham, Bradford L. (1996) 'Level playing fields and laissez faire: Postliberal development strategy in inegalitarian agrarian economies', World Development, 24/0:1-17.

Carter, Michael R. and Zegarra, Eduardo. (1995) 'Reshaping class competitiveness and the trajectory of agrarian growth with well-sequenced policy reform', Agricultural Economics Staff Paper Series No. 379, University of WisconsinMadison.

Carter, Michael R., Diana Fletschner and Pedro Olinto. (1996) 'Does land titling activate a productivity-promoting land market? Econometric evidence from rural Paraguay', University of Wisconsin-Madison.

Carter, Michael R., Shouying Liu, Michael Roth and Yang Yao. (1996) 'An induced institutional innovation perspective on the evolution of property rights in post-reform rural China', University of Wisconsin-Madison.

Cheung, N.S. (1969) The theory of share tenancy. Chicago: University of Chicago Press.

Collier, P. (1989) 'Contractual constraints on labour exchange in rural Kenya', International Labour Review, 128: 745-768.

Cramb, R.A. (1993) 'The evolution of property rights to land in Sarawak: An institutionalist perspective', Review of Marketing and Agriccultural Economics, 61/2:289-300.

De Alessi, Louis. 1980. "The Economics of Property Rights: A Review of the Evidence." Research in Law and Economics, Vol. 2: pp. 1-47.

De Janvry, A., and Sadoulet, E. (1989) 'A study in resistance to institutional change: the lost game of Latin American land reform', World Development, 17:1397-1407.

De Meza, D., Gould, J.R. (1992), 'The social efficiency of private decisions to enforce property rights', Journal of Political Economy 100:561-580

Deininger, K., P.Olinto, M.Wamulume, and D.Chiwele 1998, Agricultural sector performance in a post-reform environment: Implications for second-generation reforms in Zambia, World Bank, Waschington DC, mimeo

Deininger, Klaus (1995), Collective Agricultural Production: A Solution for Transition Economies? World-Development;23(8), August 1995, pages 1317-34..

Deininger, Klaus 1998, Making negotiated land reform work: Initial experience from Brazil, Colombia, and South Africa, World Development, forthcoming.

Dercon, Stefan and Krishnan, Pramila. (1996) 'Income portfolios in rural Ethiopia and and Tanzania: Choices and constraints', The Journal of Development Studies, 32/6:850-875.

Dercon, Stefan. (1996) 'Risk, crop choice, and savings: Evidence from Tanzania', Economic Development and Cultural Change, 44/3:485-513, The University of Chicago.

Dong, Xiao-Yuan. (1996) 'Two-tier land tenure system and sustained economic growth in post-1978 rural China', World Development, 24/5:915-928.

Dorner, P., and Thiesenhusen, W.C. (1990) 'Selected land reforms in East and Southeast Asia: their origins and impacts, Asian Pacific Economic Literature, 4:69-95.

Downs, R.W., and Reyna, S.P., eds. (1993), Land and society in contemporary Africa. Hanover and London: Published for University of New Hampshire by University Press of New England.

Dujon, Veronica. (1997) 'Communal property and land markets: Agricultural development policy in St. Lucia', World Development, 25/9:1529-1540.

Eckstein, Zvi and Itzhak Zilcha. 1994. "The Effects of Compulsory Schooling on Growth Income Distribution and Welfare." Journal of Public Economics No. 54 (July): pp. 339-359.

Ellickson, Robert C. (1993) "Property in land', Yale Law Journal,102/6:1315-1400.

Ensminger, Jean (1997), Changing Property Rights: Reconciling Formal and Informal Rights to Land in Africa, in: Drobak,John-N.; Nye,-John-V.-C., Eds., The frontiers of the new institutional economics, San Diego;London and Toronto: Harcourt Brace, Academic Press 
Eswaran, M. and A. Kotwal 1985a A theory of two-tier labor markets in agrarian economies, American Economic Review 75 , 162-177.

Eswaran, M. and A. Kotwal 1985b) A theory of contractual structure in agriculture, American Economic Review 75, 352-367.

Eswaran, M. and A. Kotwal 1986. Access to capital and agrarian production organization, Economic Journal 96, $482-498$.

Fafchamps, Marcel and Pender, John. (1997) 'Precautionary saving, credit constraints, and irreversible investment: Theory and evidence from semi-arid India'.

Feder, G, Onchan, T., Chalamwong, Y., and Hangladoran C. (1986) Land policies and farm productivity in Thailand. Baltimore, M.D.; John Hopkins University Press.

Feder, G. (1985) 'The relation between farm size and farm productivity: the role of family labor, supervision, and credit constraints', Journal of Development Economics, 18:297-313

Feder, G., and Feeney, D. (1991) 'Land tenure and property rights: theory and implications for development policy', World Bank Economic Review, 5:135-155.

Feder, Gershon and Nishio, Akihiko. (1996) 'The benefits of land registration and titling:Economic and social perspectives', The World Bank.

Feder, Gershon and Raymond Noronha 1987, Land rights systems and agricultural development in Sub-Saharan Africa Agriculture and Rural Development Dept., RU Paper 64, Washington DC

Feeney, D. (1988) 'The development of property rights in land: a comparative study', in: Bates, R.H. ed., Toward a political economy of development: a rational choice perspective. Berkely, University of California Press.

Feldstein, M. (1980) 'Inflation, portfolio choice, and the prices of land and corporate stock', American Journal of Agricultural Economics, 62:910-916.

Foster, Andrew D. and Rosenzweig, Mark R. (1996) 'Comparative advantage, information and the allocation of workers to tasks: Evidence from an agricultural labor market', University of Pennsylvania.

Frisvold, George B. (1994) 'Does supervision matter? Some hypothesis tests using Indian farm-level data', Journal of Development Economics, 43:217-238.

Fujimoto, A. (1988) 'The economics of land tenure and rice production in a double-cropping village in southern Thailand', Developing Economies, 26:189-211.

Galor, Oded and Joseph Zeira. 1993. "Income Distribution and Macroeconomics." Review of Economic Studies 60: pp. $35-52$. Oxford: The Review of Economic Studies Limited.

Gavian, Sarah and Fafchamps, Marcel. (1996) 'Land tenure and allocative efficiency in Niger', American Journal of Agricultural Economics, 78:460-471.

Geertz, Clifford. 1968. Agricultural Involution: The Process of Ecological Change in Indonesia. Berkeley: Published for the Association of Asian Studies by University of California Press.

Glaeser,-E.L. 1996, The Incentive Effects of Property Taxes on Local Governments, Public-Choice;89(1-2), 93-111..

Glover, D. (1990) 'Contract farming and outgrower schemes in East and Southern Africa', Journal of Agricultural Economics, 41 : 303-315.

Gordillo, Gustavo, Alain de Janvry, and Elisabeth Sadoulet 1997, Mexico's second agrarian reform : household and community responses, 1990-1994, La Jolla, Calif. : Center for U.S.-Mexican Studies, University of California, San Diego.

Guinnane, Timothy W. and Miller, Ronald I. (1997) 'The limits to land reform: The land acts in Ireland, 1870-1909', Economic Development and Cultural Change, 45/3:591-612, University of Chicago Press.

Gunjal,-Kisan; Williams,-Sarah; Romain,-Robert 1996, Agricultural Credit Subsidies and Farmland Values in Canada, Canadian-Journal-of-Agricultural-Economics;44(1), March 1996, pages 39-52..

Hayami, Yuiro, Adriano, L.S., Y. and M.A.R. Quisumbing 1990. Toward an Alternative Land Reform Paradigm, A Philippine Perspective Ateneo de Manila University Press, Manila

Hayami,-Yujiro; and Keijiro Otsuka 1993,The economics of contract choice: An agrarian perspective Oxford;New York; Toronto and Melbourne: Oxford University Press, Clarendon Press

Hoff, K. (1991) 'Land taxes, output taxes, and sharecropping: was Henry George right? World Bank Economic Review, 5:93-111. 
Horowitz, Andrew W. (1993) 'Time paths of land reform: a theoretical model of reform dynamics', The American Economic Review, 83/4:1003-1010.

Jalan, Jyotsna and Ravallion, Martin. (1997) 'Are the poor less well insured? Evidence on vulnerability to income risk in rural China', The World Bank.

Jensen, M.C. and W.H. Meckling 1976) Theory of the firm: managerial behavior, agency costs, and ownership structure, Journal of Financial Economics 3, 305-360.

Joakin, Jon. (1996) 'The impact of structural adjustment and property rights conflicts on Nicaraguan agrarian reform beneficiaries', World Development, 24/7:1179-1191.

Jodha, N.S. (1990) 'Rural common property resources: contributions and crisis, Economic and Political Weekly, 25: A65-A78.

Just, R.E., and Miranowski, J.A. (1989) 'U.S. land prices: trends and determinants', in: Maunder, A., and Valdes, A. eds, Agriculture and governments in an interdependent world. Proceedings of the Twentieth International Conference of Agricultural Economists, 1988.

Kevane, Michael and Bruce Wydick 1998, Social Norms and the Time Allocation of Women's Labor In Burkina Faso, mimeo.

Kevane,-Michael 1996, Agrarian Structure and Agricultural Practice: Typology and Application to Western Sudan, AmericanJournal-of-Agricultural-Economics;78(1), February 1996, pages 236-45..

King, R. (1977) Land reform: a world survey. London: G.Bell and Sons.

Koo, A.Y.C. (1968) Land reform and economic development: a case siudy of Taiwan. New York: Praeger.

Kranton, Rachel E. and Swamy, Anand V. (1997) 'The hazards of piecemeal reform: British civil courts and the credit market in colonial India', Washington: World Bank.

Kung, James Kaising. (1995) 'Equal entitlement versus tenure security under a regime of collective property rights: Peasants' preference for institutions in post-reform Chinese agriculture', Journal of Comparative Economics, 21:82-111.

Kutcher, G.P., and Scandizzo, P.L. (1981) The agricultural economy of Northeast Brazil. Washington, D.C.: World Bank.

Laffont,-Jean-Jacques; Matoussi,-Mohamed-Salah 1995, Moral Hazard, Financial Constraints and Sharecropping in El Oulja, Review-of-Economic-Studies;62(3), July 1995, pages 381-99

Lastarria-Cornhiel, Susana. (1997) 'Impact of privatization on gender and property rights in Africa', World Development, 25/8: 1317-1333.

Lieten, G.K. (1996) 'Land reforms at centre stage: The evidence on West Bengal', Development and Change, 27, 111-130.

Lin, J.Y. (1992) 'Rural reforms and agricultural growth in China', American Economic Review, 82:34-51.

Lin, Justin Yifu, Fang Cai and Zhou Li. (1994) 'Why China's economic reforms have been successful: Its implications for other reforming economies', Peking University and the Chinese Academy of Social Sciences.

Liu, Shouying, and Carter, Michael R. (1996) 'Dimensions and diversity of property rights in rural China: Dilemmas on the road to further reform', Journal of Economic Literature, Agricultural Economics Staff Paper No. 395, University of Wisconsin-Madison.

Malik, A., and Schwab, R.M. (1991) 'Optimal investments to establish property rights in land', Journal of Urban Economics, 29: 295-309.

McCarthy, Nancy, Alain de Janvry and Elisabeth Sadoulet. (1997) 'Land allocation under dual individual-collective use in Mexico', Nairobi: International Livestock Research Institute.

McCloskey, D.N. 1991. "The Prudent Peasant: New Findings On Open Fields." Journal of Economic History Vol. 51, No. 2: pp. 343-355.

McCloskey, D.N. (1975) 'The persistence of English common fields, in: Parker, W., and Jones, E. eds., European Peasants and their Markets. Princeton, N.J., Princeton University Press.

McMillan, J., Whalley, J., and Zhu, L. (1989) 'The impact of China's economic reforms on agricultural productivity growth, Journal of Political Economy, 97:781-807.

Mearns,-Robin , Community, Collective Action and Common Grazing: The Case of Post-Socialist Mongolia, Journal-ofDevelopment-Studies;32(3), February 1996, pages 297-339..

Moene, K.O. 1992, 'Poverty and Landownership', American Economic Review 82 (1992), 52-64 
Mookherjee, Dilip. (1997) 'Informational rents and property rights in land', in: J. Roemer,ed., Property Rights, Incentives \& Welfare, Macmillan Press, 1997.

Mueller, Bernardo. (1997) 'Property rights and the evolution of a frontier', Land Economics, 73/1:42-57.

Nagarajan, G., Quisumbing, M.A., and Otsuka, K. (1991) 'Land pawning in the Philippines: an exploration into the consequences of land reform regulations', Developing Economies, 29:125-144.

Newbery, D.M.G., and Stiglitz, J.E. (1979) 'Sharecropping, risk sharing and the importance of imperfect information', in: Roumasset, J.A. et al., eds., Risk, uncertainty, and agricultural development. Agricultural Development Council.

Newell, Andrew, Kiran Pandya and James Symons. (1997) 'Farm size and the intensity of land use in Gujarat', Oxford Economic Papers, 49:307-315.

Nugent, Jeffrey and Nicolas Sanchez. 1993. "Tribes, Chiefs, and Transhumance A Comparative Institutional Analysis." Economic Development and Cultural Change, Vol. 42, No. 1 (October): pp. 87-113.

Olson-Lanjouw, Jean (1995) 'Information and the operation of markets: Tests based on a general equilibrium model of land leasing in India', Economic Growth Center Discussion Paper no. 727, Yale University.

Otsuka, K. (1991) 'Determinants and consequences of land reform implementation in the Philippines', Journal of Development Economics 35:339-55.

Otsuka, Keijiro, Hiroyuki Chuma and Yujiro Hayami. (1993) 'Permanent labour and land tenancy contracts in agrarian economies: An integrated analysis', Economica 60(237), February 1993, pages 57-77..

Otsuka,-Keijiro; Chuma,-Hiroyuki; Hayami,-Yujiro (1992), Land and Labor Contracts in Agrarian Economies: Theories and Facts, Journal-of-Economic-Literature;30(4), December 1992, pages 1965-2018.

Quibria, M.G., and Rashid, S. (1984) 'The puzzle of sharecropping: a survey of theories', World Development, 12:103-114.

Reid, J.D. (1976) 'Sharecropping and agricultural uncertainty', Economic Development and Cultural Change, 24:549-576.

Robertson, A.F. (1982) 'Abusa: the structural history of an economic contract', Journal of Development Studies, 18:447-478.

Rosenzweig, M.R., and Binswanger, H.P. (1993) 'Wealth, weather risk and the composition and profitability of agricultural investments', Economic Journal 103:56-58

Rozelle, Scott, Li Guo and Loren Brandt. (1996) 'Land tenure, property rights, and productivity in China's agricultural sector', Food Research Institute, Stanford University.

Sadoulet, Elisabeth, Alain de Janvry and Seiichi Fukui. (1997) 'The meaning of kinship in sharecropping contracts', American Journal of Agricultural Economics, 79:394-406.

Sadoulet, Elisabeth, Seiichi Fukui and Alain de Janvry. (1994) 'Efficient share tenancy contracts under risk: The case of two rice-growing villages in Thailand, Journal of Development Economics, 42:243-269.

Schiff,-Maurice; Valdes,-Alberto 1995, The Plundering of Agriculture in Developing Countries Finance-andDevelopment;32(1), March 1995, pages 44-47

Scott, Maurice FitzGerald, MacArthur, J. D., Newbery, David M. G. (1976), Project appraisal in practice : the Little-Mirrlees method applied in Kenya, London : Heinemann Educational Books

Sen, A.K. (1981) 'Market failure and control of labour power: towards an explanation of 'structure' and change in Indian agriculture', parts 1 and 2, Cambridge Journal of Economics, 5:201-228 and 327-350.

Sengupta, Kunal. (1997) 'Limited liability, moral hazard and share tenancy', Journal of Development Economics, 52:393-407.

Shaban, R.A. 1991. “Does the Land Tenancy Market Equalize Holdings?" Working Paper (University of Pennsylvania).

Shaban, R.A. (1987) 'Testing between competing models of sharecropping', Journal of Political Economy, 95:893-920.

Shearer, Eric B. and Barbero, Giuseppe. (1993) 'Public policy for the promotion of family farms in Italy', The World Bank.

Shetty, S. 1988. Limited liability, wealth differences and tenancy contracts in agrarian economics, Journal of Development Economics 29, 1-22.

Sjaastad, Espen, and Bromley, Daniel (1997) 'Indigenous land rights in sub-saharan Africa: Appropriation, security and investment demand', World Development, 25/4:549-562.

Skoufias, E. (1991) 'Land tenancy and rural factor market imperfections revisited', Journal of Economic Development, 16:37-55. 
Skoufias, Emmanuel. (1995) 'Household resources, transaction costs, and adjustment through land tenancy', Land Economics, $71 / 1: 42-56$.

Southgate, E., Sierra, R., and Brown, L. (1991) 'The causes of tropical deforestation in Ecuador: a statistical analysis', World Development, 19:1145-1151.

Stiglitz, J.E., and Weiss, A. (1981) 'Credit rationing in markets with imperfect information', American Economic Review; $71: 393-409$

Strasma, J, Alsm, J., Shearer, E., and Woldstein, A. (1987) 'Impact of agricultural land revenue systems on agricultural land usage', Madison WI, Land Tenure Center, mimeo

Townsend, Robert M. (1995) 'Consumption insurance: An evaluation of risk-bearing systems in low-income economies', Journal of Economic Perspectives, 9/3:83-102.

Townsend,-Robert-M., Risk and Insurance in Village India, Econometrica;62(3), May 1994, pages 539-91..

Turner, Matthew A, Loren Brandt, and Scott Rozelle (1998), Property rights formation and the organization of exchange and production in rural China, mimeo

Udry, Christopher. (1995) 'Recent advances in empirical microeconomic research in poor countries', Northwestern University.

Udry,-Christopher (1996), Gender, Agricultural Production, and the Theory of the Household, Journal-of-PoliticalEconomy; 104(5), October 1996, pages 1010-46.

Umbeck,-John (1977), The California Gold Rush: A Study of Emerging Property Rights, Explorations-in-EconomicHistory;14(3), July 1977, pages 197-226.

Wilson, Paul N. And Gary D. Thompson. 1993. "Common Property and Uncertainty: Compensating Coalitions by Mexico's Pastoral Ejidatarios." Economic Development and Cultural Change. ., Vol. 41, No. 2: pp. 299-318. Chicago: The University of Chicago.

Yao,-Yang, Three Essays on the Implications of Imperfect Markets in Rural China University of Wisconsin, Ph.D.1996.

Zimmerman, Frederic and Carter, Michael R. (1996) 'Dynamic portfolio management under risk subsistence constraints in developing countries', Food Research Institute, Stanford University.

Zimmerman, Fredric and Carter Michael R. (1996) 'Rethinking the demand for institutional innovation: Land rights and markets in the West African Sahel', Stanford University. 
Title

WPS1993 Financial Safety Nets and Incentive Structures in Latin America

WPS1994 Estimating Wealth Effects without Expenditure Data - or Tears: with an Application to Educational Enrollments in States of India

WPS1995 What Macroeconomic Policies Are "Sound?"

WPS1996 Namibia's Social Safety Net: Issues and Options for Reform

WPS1997 On Measuring Literacy

WPS1998 The Structure and Determinants of Inequality and Poverty Reduction in Ghana, 1988-92

WPS1999 Heterogeneity among Mexico's Micro-Enterprises: An Application of Factor and Cluster Analysis

WPS2000 GATT Experience with Safeguards: Making Economic and Political Sense of the Possibilities that the GATT Allows to Restrict Imports

WPS2001 Measuring the Dynamic Gains from Trade

WPS2002 Accounting for Toxicity Risks in Pollution Control: Does it Matter?

WPS2003 Thailand's Corporate Financing and Governance Structures

WPS2004 What Can Be Expected from African Regional Trade Arrangements? Some Empirical Evidence

WPS2005 Fiscal Federalism and Macroeconomic Governance: For Better or For Worse?

WPS2006 Household Welfare Measurement and the Pricing of Basic Services
Author

Philip L. Brock

Deon Filmer

Lant Pritchett

October 1998

Mansoor Dailami

Nadeem ul Haque

Kalinidhi Subbarao

Kaushik Basu

James E. Foster

Sudharshan Canagarajah

Dipak Mazumdar

Xiao Ye

Wendy $V$. Cunningham

William F. Maloney

J. Michael Finger

Romain Wacziarg

Susmita Dasgupta

Benoit Laplante

Craig Meisner

Pedro Alba

Stijn Claessens

Simeon Djankov

Alexander Yeats

Anwar Shah

Jesko Hentschel

Peter Lanjouw
Date

October 1998

October 1998

November 1998

S. Valle

84493

Contact

for paper

K. Labrie 38256

S. Fallon 38009

B. Nedrow 31585

P. Lizarondo 87199

M. Mason 30809

A. Garscadden 38400

T. Gomez 32127

L. Tabada 36896

November 1998

S. Crow

November 1998

Y. D'Souza 31449

November 1998

R. Vo 33722

November 1998

L. Tabada 36896

November 1998

PREM

87736 30763 


\section{Policy Research Working Paper Series}

Title

WPS2007 Regional Integration Arrangements: Static Economic theory, Quantitative Findings, and Policy Guidelines
Author

Dean A. DeRosa

Pedro Alba

Amar Bhattacharya

Stijn Claessens

Swati Ghosh

Leonardo Hernandez

WPS2009 Poverty and the Economic Transition: How Do Changes in Economies of Scale Affect Poverty Rates for Different Households?

WPS2010 The Real Impact of Financial Shocks: IIker Domaç Evidence from the Republic of Korea Giovanni Ferri
WPS2011 Measuring Poverty Using Qualitative Menno Pradhan Perceptions of Weifare
Martin Ravallion
WPS2012 Export Quotas and Policy Constraints Sanjay Kathuria in the Indian Textile and Garment Industries
Anjali Bhardwaj

WPS2013 A New Database on Investment and Capital for Agriculture and Manufacturing
Branko Milanovic

Stefano Paternostro

November 1998

November 1998

November 1998

Al Crego

Donald Larson

Rita Butzer

Yair Mundlak

November 1998
Contact

for paper

\author{
November 1998 \\ L. Tabada \\ 36896
}

November 1998

D. Fischer 38656

P. Sader 33902

M. Greaves 81876

P. Sader 33902

November 1998 L. Tabada 36896

P. Kokila 33716 